\title{
Artelogie
}

Recherche sur les arts, le patrimoine et la littérature de l'Amérique latine

1 | 2011

Brésil, questions sur le modernisme

\section{Regionalistas e cosmopolistas: As amigas Olivia Guedes Penteado e Carlota Pereira de Queiroz}

\author{
Mônica Raisa Schpun
}

\section{OpenEdition}

Journals

Edição electrónica

URL: https://journals.openedition.org/artelogie/8752

DOI: $10.4000 /$ artelogie.8752

ISSN: 2115-6395

\section{Editora}

Association ESCAL

Refêrencia eletrónica

Mônica Raisa Schpun, «Regionalistas e cosmopolistas: As amigas Olivia Guedes Penteado e Carlota Pereira de Queiroz», Artelogie [Online], 1 | 2011, posto online no dia 01 março 2011, consultado o 07 janeiro 2022. URL: http://journals.openedition.org/artelogie/8752 ; DOI: https://doi.org/10.4000/ artelogie. 8752

Este documento foi criado de forma automática no dia 7 janeiro 2022.

Association ESCAL 


\section{Regionalistas e cosmopolistas: As amigas Olivia Guedes Penteado e Carlota Pereira de Queiroz}

Mônica Raisa Schpun

No Egito, em frente às pirâmides

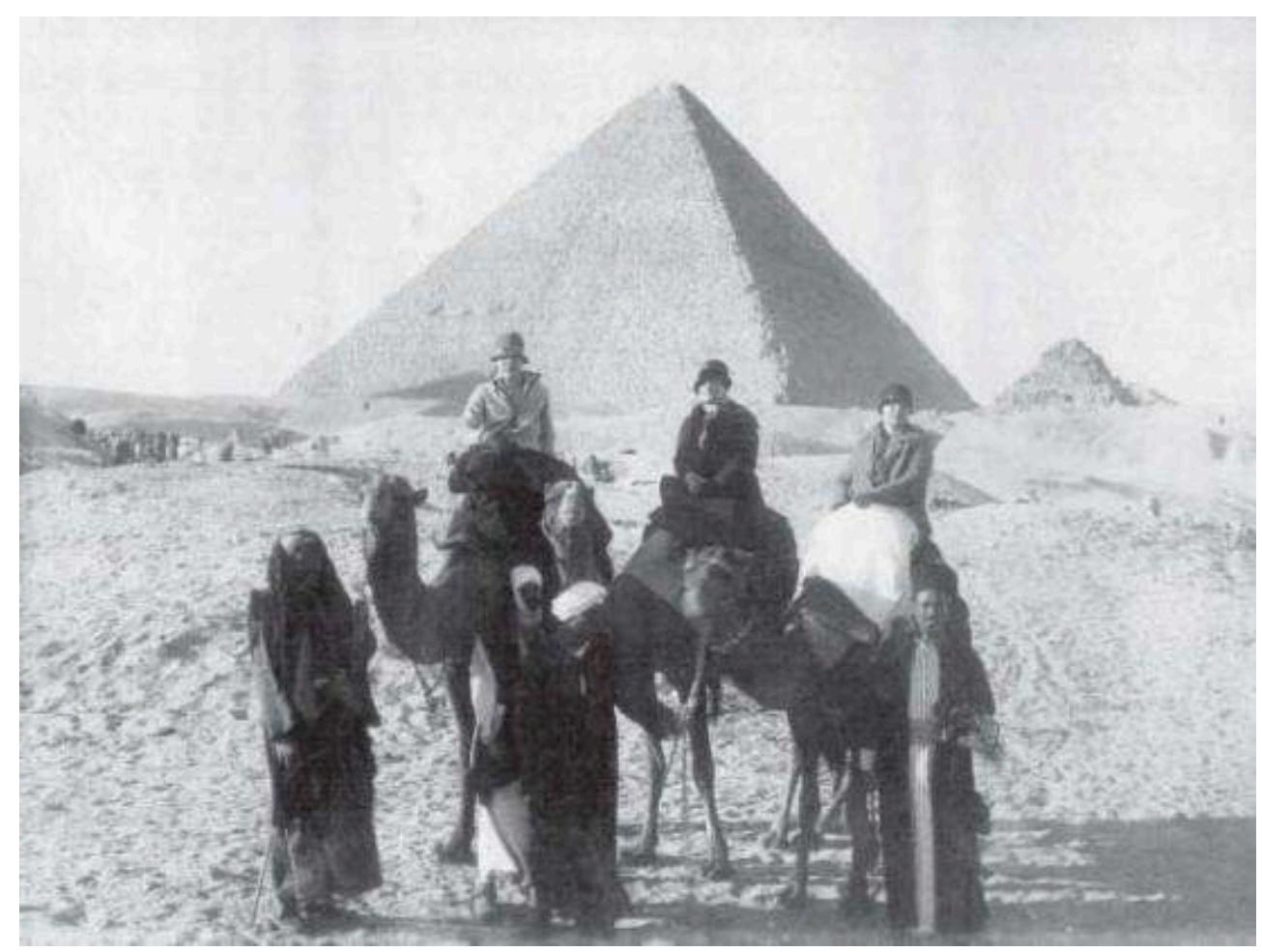

Da esquerda para a direita: D. Baby Ramos, D. Olivia Guedes Penteado e Dra. Carlota Pereira de Queiroz 
1 Em $1^{\circ}$ de outubro de 1925, José Pereira de Queiroz escrevia à filha Carlota, então estudante de Medicina no Rio de Janeiro:

Carlota

Recebi sua carta. Respondo-lhe com toda franqueza.

Você é, além de maior, ajuizada, tem posição propria e dê à minha opinião o valor que entender que ella merece. (...)

Acho sua viagem ainda menos acertada do que a que Vocês pretendiam fazer com o Jordão [viagem finalmente não realizada para Buenos Aires, alguns meses antes].

Por ser D. Olivia rica, não é razão para acceitarmos seus favores, não se tratando de necessidade premente nossa e de força irresistivel. Não ha razão para acceitarmos seus sobejos. Não devemos ir nos escravisando e tornando dependentes de outros, principalmente por motivos bem dispensaveis. (...) Os habitos, a educação, o meio, a situação e mtas outras cousas de D. Olivia são mto differentes dos nossos

Depois a questão financeira. Ella dar-lhe-á a passagem, que, note bem, não é de excursão com direito a outras vantagens, além da viagem propriamente. Voce não ha de pedir à D. Olivia o que Você precisar para desembarques, hoteis, passeios, estradas de ferro, etc, etc. Por menos que V. gaste, precisa levar dez contos, pelo menos; infelizmente eu não os tenho para dar nem para lhe adiantar. Você não deve vender ou empenhar sua casa para essas despezas ou outras semelhantes. Ella é único recurso providencial e casual que V. tem e com o qual tem podido custeiar mais ou menos seus estudos.

Acceite nossas saudades e abrace quem pode ser rabujento, mais é com sinceridade Seu pai affetuoso,

Zezinho

2 O assunto que leva Carlota (1892-1982) a pedir a opinião paterna é uma viagem para o Oriente, para a qual a amiga D. Olivia (1872-1934) acabara de convidá-la. Aparentemente, a posição do pai deve-se, antes de mais nada, a experiências pessoais e negativas que viveu:

Voce naturalmente ficou aborrecida com a franqueza de seu Pae, mas diz elle que outra cousa não lhe podia dizer e que elle só sabe o quanto lhe tem amargado o escravisar-se, por favores, aos outros.

Em todo caso elle lhe mandou dizer que resolva como entender (...). (Maria Vicentina de Azevedo Pereira de Queiroz, carta à filha Carlota, 5 de outubro de 1925)

Carlota segue então o conselho enviado pelo pai, cinco dias após seu desabafo sincero, através das mãos da mãe, e resolve "como entende": apesar dos escrúpulos paternos, aceita o convite, sem vender nem empenhar sua casa. Aliás, após o desabafo citado, as cartas paternas desvelam a existência de uma reflexão familiar sobre a situação financeira de Carlota. Avaliando o quadro geral, o próprio e o irmão mais velho, Manoel Elpídio, aconselham-na a não vender nem hipotecar a casa somente pelos dez contos necessários à viagem.

E D. Olivia também parece consciente da diferença entre a situação da amiga e a sua:

A viagem vai correndo explêndida e D. Olivia tem sido excessivamente bôa para mim. Interessa-se por tudo que faço, pelo meu bem estar e tranquilidade com verdadeira amizade. Gastos não tenho tido e nem ella consente que os tenha. (...) As excursões ella já tomou e não me deixou absolutamente pagar. (Carlota Pereira de Queiroz, carta aos pais, 19 de dezembro de 1925) ${ }^{1}$

Como indica a conversa epistolar que Carlota mantém com o pai e, indiretamente, com o irmão, sua situação financeira exige uma certa reflexão ante a decisão de dispor dos tais 10 contos para empreender viagem. A meu ver, duas razões principais justificam sua decisão; elas constituem o eixo das observações que farei a seguir. 
6 A curiosidade de espírito de Carlota encontra uma possibilidade privilegiada de expressão diante de uma viagem a terras absolutamente desconhecidas e cobertas de exotismo. O roteiro percorrido, é preciso ter em mente, entre 1925 e 1926, incluiu os seguintes pontos, dentre outros: Tanger, Tripoli, Alexandria, Egito, Palestina, Istambul (designada Constantinopla por Carlota) e Atenas.

7 Se, em outras viagens feitas à Europa, Carlota manifesta seu gosto acentuado pelas artes, indo a concertos, teatros e museus, informando-se do melhor modo possível sobre os acontecimentos culturais disponíveis, nesta experiência turística é o exotismo que mais atrai sua atenção:

Os habitos, costumes, modo de vestir e de viver, tudo é differente aqui [Tanger, primeira etapa da viagem]. Como começo de uma viagem de impressões exoticas como vae ser essa não podia ser melhor. (Carlota Pereira de Queiroz, carta aos pais, 23 de outubro de 1925$)^{2}$

Descemos hoje em Tripoli ás 2 horas. Arabes em costumes caracteristicos, asnos e camellos dão um carater especial à cidade.

(...)

Amanhã vamos a convite do Governo Italiano visitar umas novas excavações que estão fazendo no deserto, onde descobriram uma antiga cidade romana. Visitaremos tambem um oasis.

Almofadas de couro, tapetes e esteiras ha lindos por aqui. Só sinto não ter bastante dinheiro, porque ha cousas muito curiosas à venda. Hoje entramos numa mesquita arabe. Era imponente pelo luxo e riqueza. (Carlota Pereira de Queiroz, carta aos pais, 7 de janeiro de 1926)

Constantinopla é hoje uma cidade européia, muito extensa e populosa. 0 "fez" está abolido e não há mais damas veladas. Acho que antes seria mais interessante para nós (Carlota Pereira de Queiroz, carta à mãe, 24 de janeiro de 1926)

No Egito, fascina-se pela grandiosidade dos monumentos da Antiguidade; em Jerusalém, é o sagrado que marca seu espírito, visitando os lugares santos do cristianismo.

8 Contudo, independentemente do interesse particular que as diferenças culturais acentuadas despertam em Carlota, o cruzeiro é, em si, motivo de grande excitação. Por diversas vezes manifesta seu gosto pelas viagens e seu deslumbramento pela descoberta do novo:

Acho que o mez de Março [após a volta] vae ser curto para contar tudo o que vi. É realmente uma cousa bôa viajar. Recordo geografia, história, arte, tudo e ainda desenvolvo o espírito de observação. Vou trabalhar com coragem para voltar um dia. (Carlota Pereira de Queiroz, carta à mãe, 27 de janeiro de 1926)

9 Além disso, o aspecto aventureiro destaca-se na experiência, dando maior sabor a monumentos paisagens e sociedades, repletos de exotismo e mistério. A viagem foi feita de navio, de trem, de caminhão, em estradas nem sempre seguras e em rotas às vezes pouco exploradas pelo turismo. Se a Itália também foi foco da visita, esta não comprendeu as cidades do Norte (com exceção do porto de Genova) e nem mesmo Roma, que D. Olivia já conhecia e não quis visitar novamente:

No dia 2 fomos a Capri, vêr a gruta azul. É uma verdadeira maravilha. Sahimos ás 8 da manhã e voltamos ás 7 da noite, mas valeu a pena.

Hontem (...) visitamos Pompeia. Fiquei extasiada diante do luxo e da grandeza que revelam aquellas ruinas. (...)

Hoje fomos ao Vesuvio, excursão que não recommendo a ninguem dos que quero bem. Fomos à bocca da cratera, onde morreu Silva Jardim. Cada pessôa é conduzida por um guia na montanha escarpada e coberta de lavas cinza e pedras revoltas. (...) O dia estava frio, mas ficámos exhaustas. Não nos haviam prevenido e fomos todas de salto alto, o que foi muito 
incommodo. O vulcão estava em franca erupção. Alem da fumaça que delle sáe constantemente ouvimos varias detonações, linguas de fogo e uma vez precisámos nos affastar para fugir das pedras incandescentes que elle lançava. (...) Eu não cheguei tão perto de medo, mas peguei duas pedras ainda quentes, que levarei para verem. Houve uma hora em que ficámos suffocadas pelas emanações de enxofre. Vocês não imaginam a fumaça que sahia da terra, mesmo á distancia. (Carlota Pereira de Queiroz, carta aos pais, 4 de janeiro de 1926)

A visita a Leptis Magna, a cidade romana que os italianos estão desenterrando das areias do deserto, foi a melhor surpreza da viagem até agora. (...) Viajamos 8 horas de caminhão para ir vê-las. (Carlota Pereira de Queiroz, cartão postal com imagem de Tripoli, endereçado à mãe, 13 de fevereiro de 1926, expedido de Gênova após sua partida da cidade) ${ }^{3}$

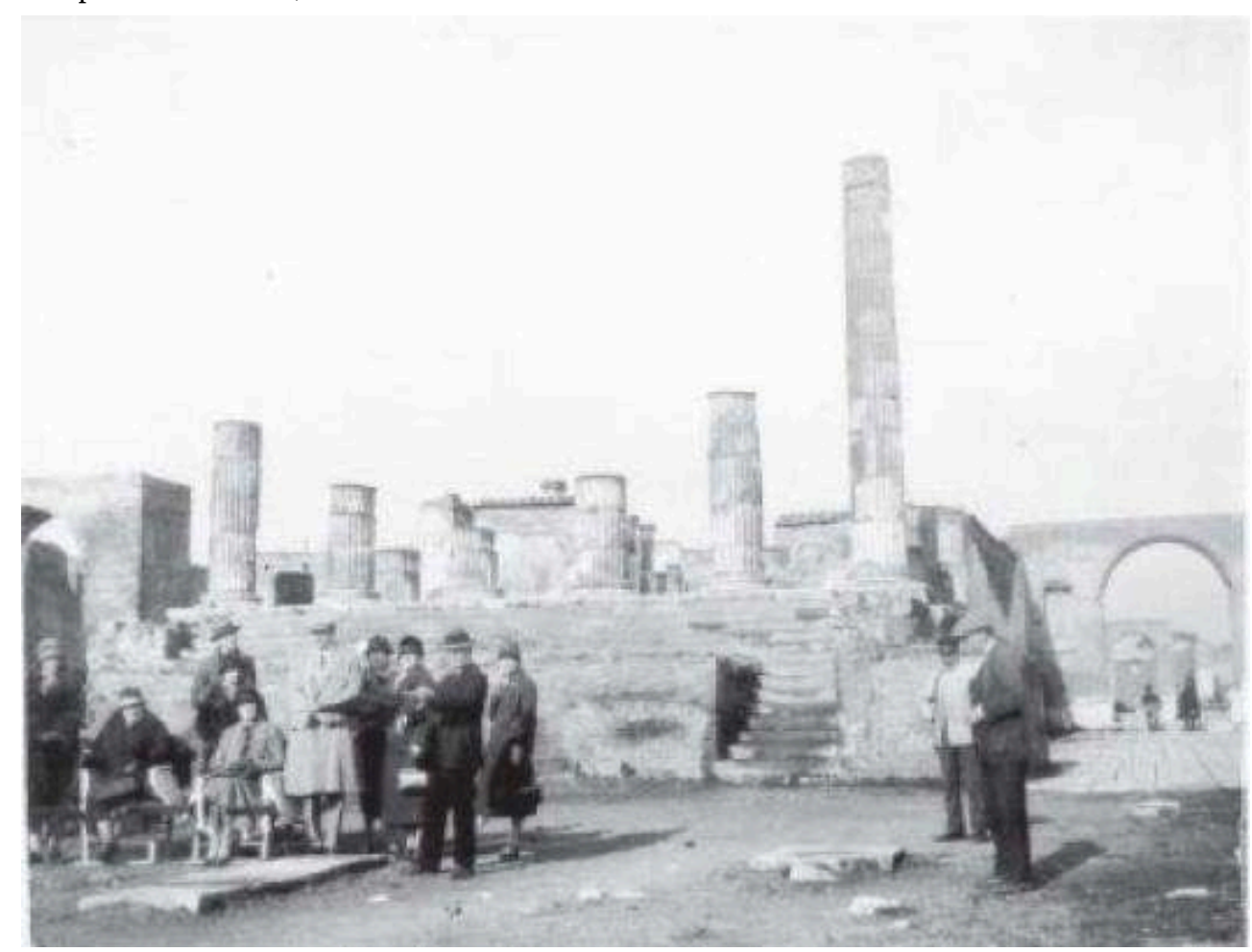

Para além do aspecto pitoresco desta série de passagens epistolares, uma informação histórica reúne e explica a seqüência de citações e observações feitas acima. 


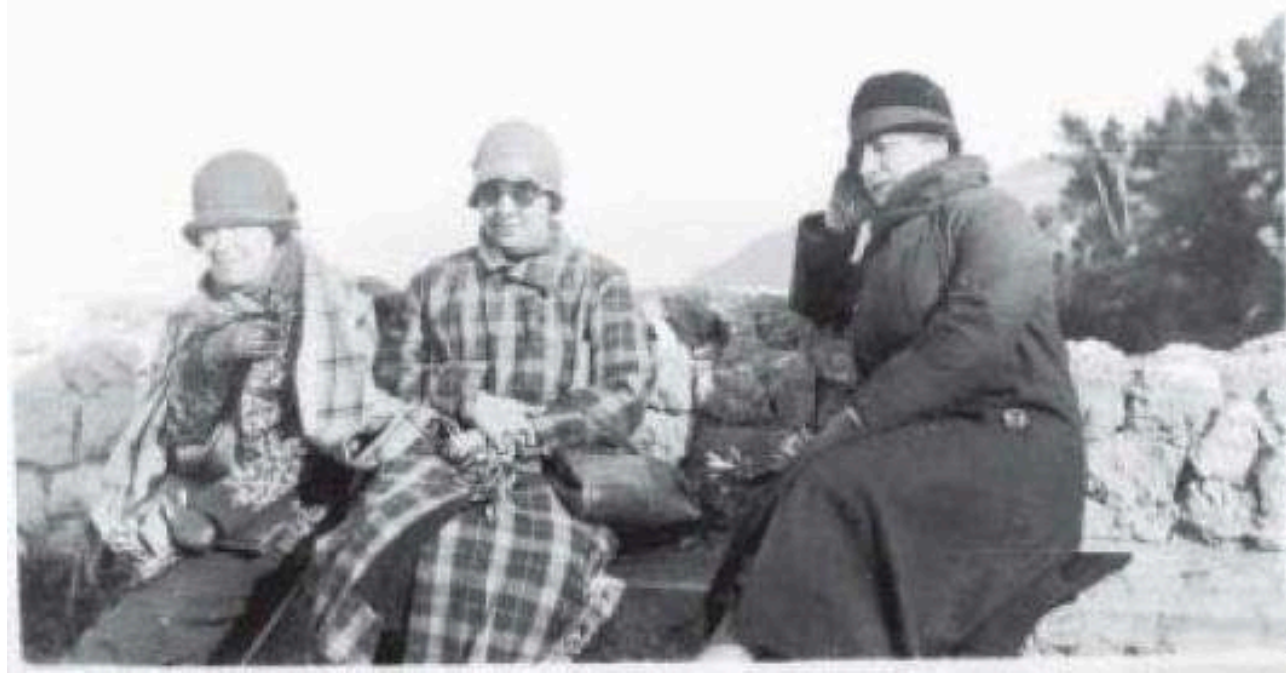

11 Muito se tem falado do caráter afrancesado das elites brasileiras e, mais particularmente, para o que nos interessa aqui, das elites cafeicultoras, ou simplesmente paulistas. É verdade que o fascínio exercido pela França, e sobretudo por sua capital, junto ao grupo pode ser verificado em diversos aspectos da vida social, das mentalidades, dos hábitos e costumes. As constantes e longas viagens a Paris fizeram parte integrante da vida das ditas "antigas famílias" paulistas. D. Olivia é, quanto a isso, um exemplo paradigmático, por suas longas permanências na capital francesa, pelo papel-chave que exerceu seu apartamento parisiense na vida mundana das elites locais de passagem por ali. Carlota, despossuída não somente de situação financeira que lhe permitisse longas e constantes permanências em Paris, mas também da disponibilidade correlata de tempo e dinheiro exigida para a freqüentação habitual do espaço seleto de reuniões que foi o apartamento de D. Olivia, nem por isso desmente a atração exercida pela cidade junto a seu grupo de pertença ${ }^{4}$. Assim, em 1923, ela encontra-se na Europa, numa viagem que tem por objetivo central levar a irmã a uma estação de cura na Suiça. A passagem por Paris é, porém, inevitável e ali encontra a amiga D. Olivia. Mais tarde, em 1926, uma semana em Paris marca, para ambas, o final do cruzeiro pelo Oriente. Nesta viagem, se Carlota consegue reter-se diante dos baixos preços de objetos raros, exóticos e tentadores, reduzindo suas despesas praticamente a filmes para a máquina fotográfica, postais e selos, ela o faz pensando em guardar o orçamento de que dispõe para compras em Paris. Em 1927, logo após a obtenção de seu diploma médico, Carlota volta à Europa, desta vez para uma estada mais longa, durante a qual faz cursos de especialização na França, na Alemanha e na Suiça. Nesse período, a correspondência com a família também indica hábitos que poderíamos chamar de "afrancesados", tentanto porém tirar do termo uma conotação moralmente pejorativa que lhe é quase sempre associada. As compras e pedidos de roupas, produtos alimentares, bebidas, objetos decorativos e de uso doméstico indicam uma grande familiaridade com a 
França, a leitura constante de catálogos e revistas, o conhecimento de lojas e ateliês de costura parisienses, o consumo bastante habitual de produtos franceses pelos pais, irmãos, parentes e amigos de Carlota. As listas de encomendas, os comentários feitos em relação àquilo que foi solicitado, àquilo que foi ou não encontrado e as contas detalhadas do crédito de cada um, sobretudo dos membros da família, com as respectivas despesas, ocupam um espaço dominante nessa correspondência, trazendo diversas informações interessantes.

12 A gestão cotidiana dos diversos créditos e encomendas, muitas vezes complicadas e em constante revisão, de ambos os lados da correspondência, indica o caráter familiar e já incorporado de tais práticas que, ao leitor contemporâneo, podem parecer trabalhosas. Ora, Carlota privilegia claramente a vida cultural e os estudos, quanto ao emprego do seu tempo cotidiano. Mesmo assim, não descuida das compras e pedidos, nem do tempo gasto com estes e com os constantes relatórios inclusos nas cartas: tal investimento não parece ser contabilizado nem ela dá sinais de querer economizá-lo. As relações com a família distante e as imensas saudades tão freqüentemente expressas encontram nesta troca afetiva de favores um modo de compensação.

13 Além disso, as cartas indicam a existência de um cálculo sempre preciso quanto às vantagens e desvantagens envolvidas em cada compra. A produção brasileira não supre ainda as necessidades de consumo ressentidas por essas elites, que vivem às voltas com produtos importados, sobretudo no que tange ao vestuário e à alimentação. E isso inclui famílias que não ocupam uma posição paradigmática de fausto e riqueza, como é o caso em questão, para as quais vale a pena adquirir na Europa (em Paris, essencialmente) produtos que, no Brasil, custariam muito mais, pois importados. O raciocínio empregado é, quase sempre, o de aproveitar a oportunidade não somente da maior beleza e qualidade daquilo que se compra, mas sobretudo dos preços vantajosos. Quando estes não o são, e isso acontece em alguns casos, a encomenda é abandonada.

O "afrancesamento" das elites pode ser lido em atitudes as mais diversas, desde aquelas descritas aqui até outras, menos cotidianas, menos corriqueiras, mais carregadas de mundanidade e sofisticação, como a de viajar, nos moldes feitos nos mesmos anos 1920 por Antonio Prado Jr. e Numa de Oliveira, para comprar em Paris equipamentos de tênis (redes, raquetes, bolas) para o Club Athlético Paulistano; ou ainda a de manter um apartamento fixo em Paris, como o fez D. Olivia. Em todos esses exemplos, e em tantos outros, as diferenças dependem, antes de mais nada, do grau de acesso ao consumo e dos hábitos que então se criam. A familiaridade com produtos, modas, gostos e hábitos europeus, particularmente franceses, é comum a essas elites. E o gosto pelas viagens também. Contudo, a impregnação da cultura francesa no seio do grupo atinge dimensões que ultrapassam a da presença, em suas casas, de objetos, roupas, marcas e etiquetas adquiridas diretamente na França ou trazidas pelos vapores. Trata-se de uma admiração cultural já tradicional, que introduz hábitos de leitura, familiaridade particular com a língua, com a história, as artes e a cultura do país. Carlota tem muitas ligações com a França, ligações profissionais, com colegas e amigos médicos, ligações de amizade, com várias famílias francesas, um convívio com a representação diplomática francesa no Brasil, tendo sido agraciada, nos anos 50, com a Légion d'Honneur. E o mesmo traço identifica na amiga, em tom elogioso:

A influencia francesa foi grande na mentalidade de D. Olivia. Justifica esse fáto a permanencia de longos anos em Pariz, onde chegou a residir, acompanhando o marido enfermo e educando primorosamente suas duas filhas. ${ }^{5}$ 


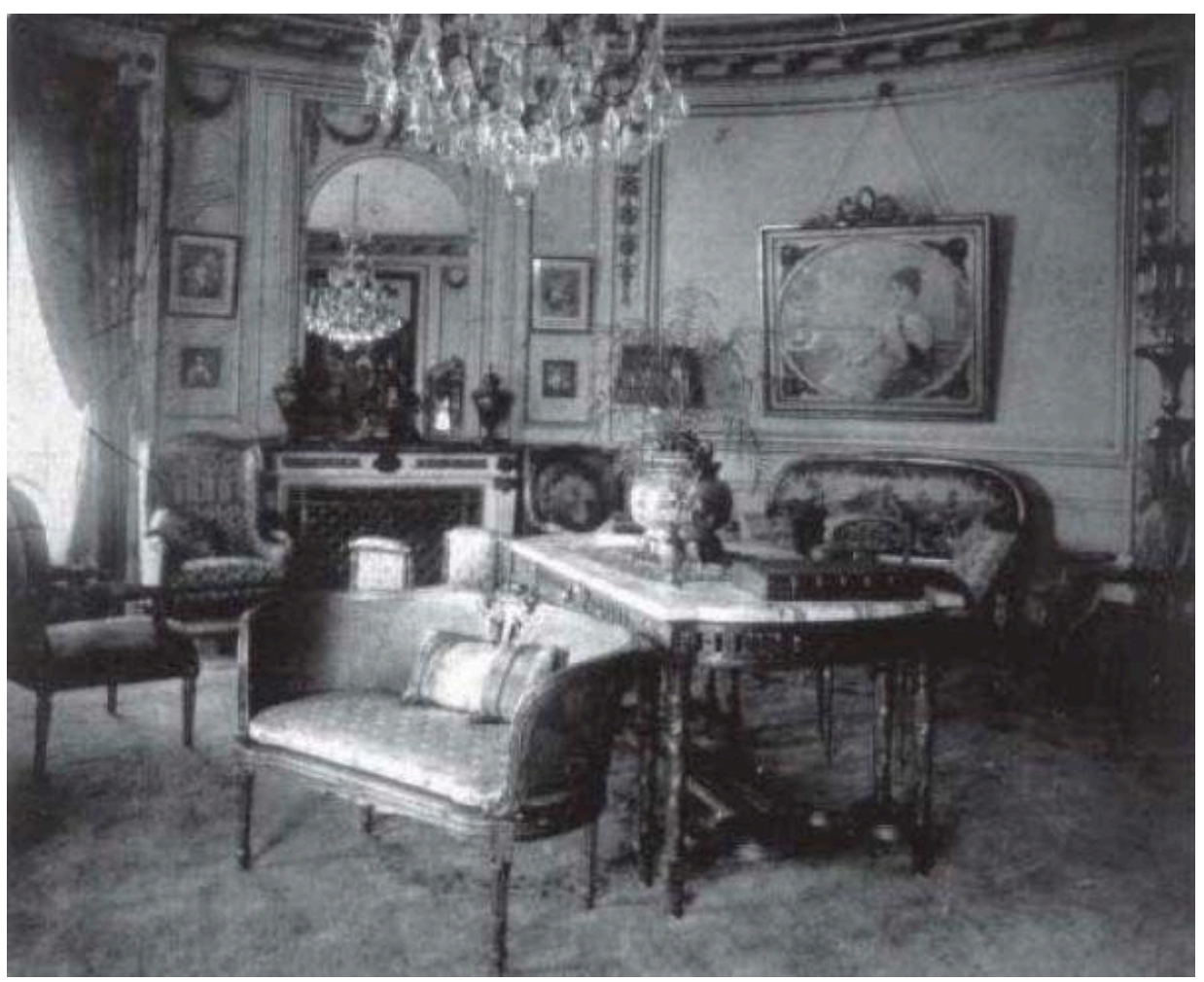

15 Segundo o Dicionário Houaiss, a palavra cosmopolitismo data, em português, de 1873; já a palavra cosmopolita apresenta seu primeiro registro em nossa língua um pouco antes, em 1836. Trata-se, contudo, do século XIX, século das viagens turísticas e das grandes levas de imigração que atravessaram o Atlântico e deram origem, nas Américas, a grandes - e cosmopolitas - cidades. O cosmopolitismo das elites paulistas não é aquele que habitualmente se lê na São Paulo do início do século XX, com suas diversas comunidades imigrantes, sua cultura urbana eclética, sincrética, ricamente composta. As elites da época não convivem com tal ambiente, mas vivem, de certo modo, numa cidade dentro da cidade, com espaços e circuitos de freqüentação exclusivos, evitando ao máximo uma proximidade física com aqueles - imigrantes e outros - cuja distância social é enorme.

O cosmopolitismo do grupo refere-se, essencialmente, a uma relação de familiaridade já tradicional com a Europa e com os seus centros urbanos difusores de cultura, informação, moda, padrões de sofisticação e de beleza. Trata-se, ao mesmo tempo, de hábitos de distinção social e de traços comuns, de reconhecimento mútuo, interno ao grupo. Estes não são, evidentemente, os únicos fatores de distinção, nem de coesão grupal, mas funcionam, neste sentido, de modo muito eficaz. A ponto de estarem extremamente enraizados, de parecerem naturais, como procurei demonstrar no exemplo das encomendas feitas a Carlota pelos seus.

17 Na mesma lógica, para dar um último exemplo, eloqüente (já que mencionei a cidade dentro da cidade), o Teatro Municipal de São Paulo, inaugurado em 1911, foi diretamente inspirado no Opéra de Paris. Ele trouxe ao centro da cidade, ajardinado ao gosto das elites do café, um edifício que correspondia ao seu imaginário, não somente "afrancesado", mas cosmopolita. o traço que se destaca, do ponto de vista da informação histórica, não é o da imitação, que leva imediatamente a um juízo moralista 
e obrigatoriamente desvalorizador. Importa, isto sim, perceber que - e como - as famílias destas elites adquirem assim, em sua própria cidade, um espaço de encontro e de fruição cultural a seu gosto, identificam-se com os momentos passados ali dentro, com o ambiente, os programas propostos, renovando sensações, experiências e situações que lhes são caras. E que, nem por isso, deixarão de buscar e vivenciar nos teatros europeus.

Sala lateral da casa da Av. Conselheiro Nébias, S. Paulo

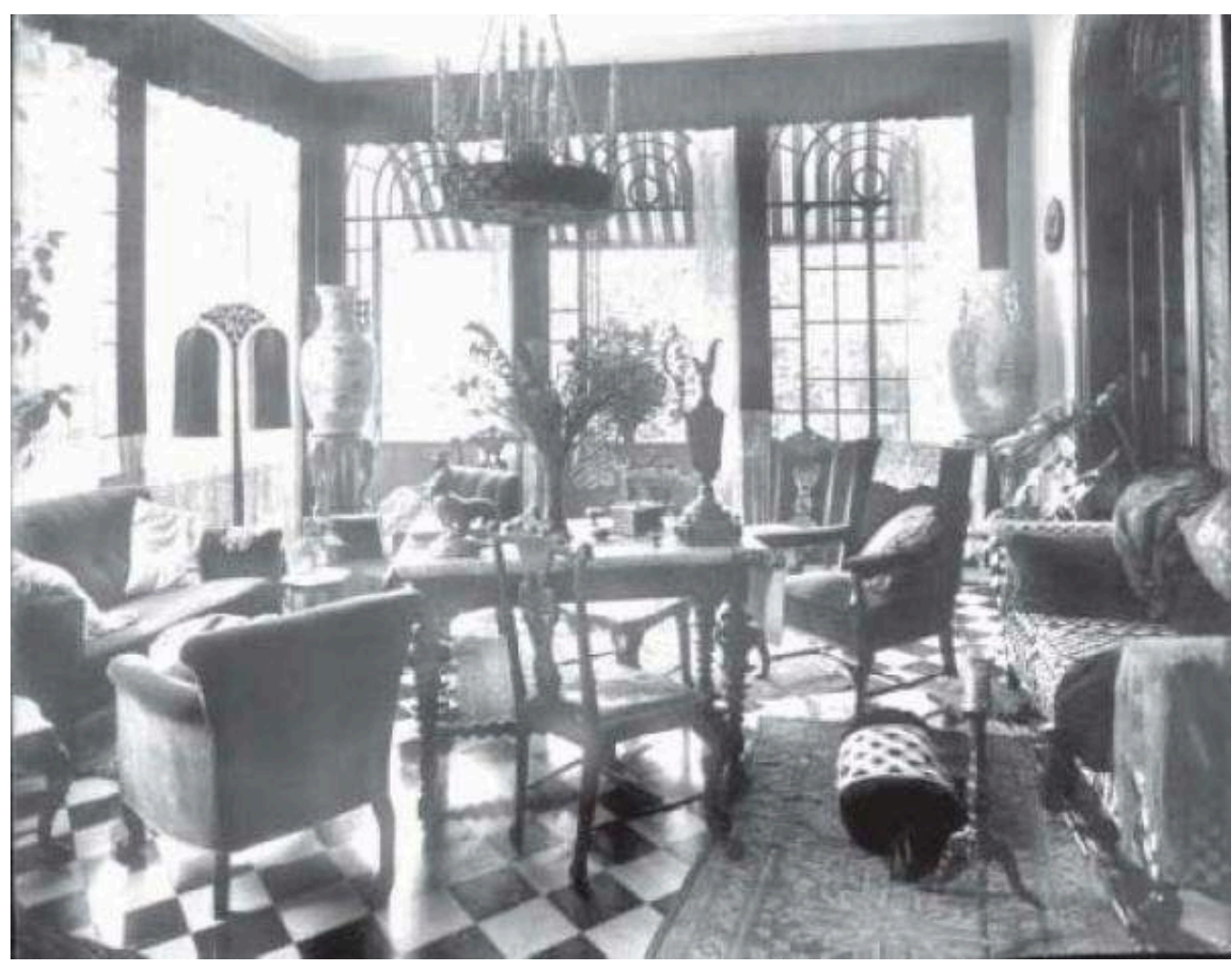

Este o cosmopolitismo das elites, que se manifesta também, e de forma privilegiada, no prazer acentuado pelas viagens. Como vimos nos trechos transcritos da correspondência de Carlota, tal prazer parece aumentar na mesma proporção em que as realidades observadas afastam-se do já conhecido, e menos surpreendente, mundo Ocidental. Ora, não existe qualquer contradição entre, de um lado, a atração exercida sobre o grupo em questão pela "cidade luz", com sua oferta de vida cultural e a conotação de elegância e sofisticação que a envolve e, de outro, a sedução provocada pelo exótico. Nos dois casos, estamos diante do mesmo cosmopolitismo, curioso, amante das viagens, das novidades, descobertas e distâncias, e de um sentido habitualmente dado ao termo cultura, ligado ao aprendizado e à aquisição de familiaridade com a Arte e a História, através da visita a monumentos, museus e cidades, através da freqüentação de exposições, espetáculos e concertos. Tais hábitos, e a bagagem que produzem, são muito valorizados e cultivados por essas elites, sobretudo por suas frações mais intelectualizadas, como é sem dúvida o caso aqui examinado.

19 Nessa educação dos gostos e nessa familiarização com as artes e a cultura, assim entendida, inclui-se também um apreço acentuado do grupo aqui examinado pelas artes decorativas. $\mathrm{O}$ hábito de decorar, senão construir, seus palacetes paulistanos com objetos e materiais europeus é conhecido. $\mathrm{Na}$ viagem ao Oriente, bandejas e outros 
objetos em cobre, almofadas de couro e tapetes atraem o olhar de Carlota. Isso não indica nenhum excentrismo de sua parte; nem sua personalidade era dada a tal, nem seu gosto, antes voltado às peças antigas de mobiliário e a ao colecionismo de antiguidades em geral. Entretanto, os objetos "exóticos" vistos entre a África e a Ásia, não entram em contradição um gosto de tipo mais clássico; eles testemunham, antes de mais nada, o gosto pelas viagens e a longa empresa realizada, até longínquos cantões.

Enfim, uma abertura modernizante existe, no sentido de incluir no espectro daquilo que é considerado e apreciado como expressão artística, histórica e cultural, manifestações de sociedades não ocidentais, como aquelas visitadas com a amiga D. Olivia, cujas tradições fogem aos códigos já absorvidos. Isso sem trair ou ameaçar a bagagem sócio-cultural e o horizonte de valores que carregam: nem Carlota nem Dona Olivia rompem com os padrões que identificam sua origem e pertença social. 0 cosmopolitismo do grupo inclui também um interesse, mais ou menos mundano, mais ou menos estudioso e informado por outras civilizações, sociedades e culturas, pela "aventura" da descoberta do novo.

21 Os anos vinte são um período áureo para as tendências e idéias nacionalistas, para a busca da identidade nacional e a construção de elementos de coesão coletiva. O modernismo é um dos modos de expressão desta nova sensibilidade - presente também em outros discursos, esforços e iniciativas - que acabou por tornar-se um cânone dominante - e extremamente exigente - nas artes, na literatura e no pensamento em geral. A descoberta da brasilidade e a valorização do Brasil, em todos os seus aspectos, impôs-se às elites culturais, intelectuais e artísticas.

22 Não me parece, contudo, que D. Olivia tenha traçado uma linha hierarquizante entre suas viagens pelo Brasil e as outras, pelo exterior. E o caráter aventureiro e rústico, tantas vezes lembrado em relação à viagem -pela Amazônia - para aumentar o significado de uma dama de sua posição realizar tal empresa -, já tinha sido vivido em mais de uma etapa do cruzeiro feito com Carlota, como pudemos constatar. Resta saber se a descoberta de Minas, feita pelos modernistas junto com a amiga e mecenas, teria despertado nesta mais entusiasmo e trazido realmente mais "descobertas" do que outras tantas experiências que possa ter tido em outras partes. Segundo discurso feito por Carlota, na já citada homenagem póstuma prestada à amiga, não parece ser o caso:

Nos ultimos anos de sua vida viajou muito. Foi varias vezes á Europa, numa das quaes até a Suecia e a Noruega; fez um Cruzeiro ao Oriente em que tive a ventura de acompanhá-la. E, si não deixou notas de viagem, posso rapidamente traduzir as suas impressões, que sabia transmitir com grande encantamento.

$\mathrm{O}$ sol da meia noite deicou-lhe uma lembrança indelével. E, num Cruzeiro ao Oriente, que foi uma viagem de sonho, em 1925, vi-a viver horas de intensa emoção.

O paradigma nacionalista privilegia sem dúvida as viagens pelo Brasil. Além disso, um julgamento moral persiste e tende a considerar as viagens a Minas a à Amazônia como iniciativas que provam qualidades pessoais e que destacam D. Olivia do grupo social ao qual pertence, diferenciando-a da tendência geral, "afrancesada". Ora, suas relações com os modernistas, às quais se ligam as viagens pelo Brasil, singularizam-na seguramente no seio das elites locais. Mas o que não é levado em conta, pelo juízo em questão, é que tais viagens e a faceta modernista e mesmo nacionalista de D. Olivia convivem sem contradições com outras facetas também suas - e não menos suas -, como aquelas que encontram expressão durante suas longas permanências em Paris, suas viagens à Europa, e seu cruzeiro pelo Oriente, cheio de novidades, de aventuras e 
de exotismo. E, a meu ver, tais novidades, e o exotismo de que se cobrem, não são menos intensas ou até mesmo, arriscaria dizer, menos longínquas do universo cultural ao qual pertence, do que aquilo que descobre com seus amigos modernistas, pelo interior de Minas Gerais e pelo Norte do país.

Não pretendo absolutamente dizer que D. Olivia ou Carlota sejam despidas de sentimentos de tipo nacionalista. O que seria incorreto e mesmo inútil. Pretendo entretanto mostrar que hierarquias construídas, em geral a posteriori, atrapalham a leitura que podemos fazer dos atores sociais em toda sua complexidade.

\section{... e amizade sincera}

\section{elementos comuns aproximam Carlota de D. Olivia, tornando agradável a ambas o longo} cruzeiro e outras tantas situações de lazer que condividem:

Fomos numas excursões que o Cook organisa, D. Olivia e eu. (Carlota Pereira de Queiroz, carta ao pai, Paris, 14 de agosto de 1923)

E a amizade é forte e recíproca, justificando não somente a aceitação, por parte de Carlota, do convite feito por D. Olivia mas, evidentemente, a iniciativa desta última, que convida e reivindica a companhia da amiga:

Ha dias, tendo Fanny ${ }^{7}$ me perguntado quaes os meus planos sobre Pariz, D. Olivia interrompeu com a pergunta: “- Você vae ficar commigo, não, Carlota ?" (Carlota Pareira de Queiroz, carta aos pais, 19 de dezembro de 1925)

A simpatia mútua que liga as duas amigas explica então, ao lado da curiosidade e do gosto pelas viagens, também comuns a ambas, a decisão tomada por Carlota, de partir rumo ao Oriente, ao lado de Olivia Guedes Penteado.

E tal simpatia afirmar-se-á ainda mais após o regresso a São Paulo. De fato, nos anos trinta, a convivência e a identificação entre as amigas terão outras tantas ocasiões de se expressar. Ocasiões de um tipo bastante diverso daquele que estive tratando até agora, e que abordarei em seguida. 


\section{Envolvimentos regionalistas}

Eleita para a Assembléia Nacional Constituinte, em 3 de maio de 1933, pela Chapa Única por São Paulo Unido !, Carlota Pereira de Queiroz foi a primeira mulher a ocupar um cargo de deputado federal no Brasil e a única a assinar a Constituição de 1934, ao lado dos outros 252 constituintes, todos homens. Finda a Constituinte, ela é re-eleita, a 14 de outubro de 1934, desta vez para um mandato na Câmara Federal, pelo então recémcriado Partido Constitucionalista ${ }^{8}$.

Pequena sala da casa de D.Olivia. Presa informalmente à parede foto de Carlota

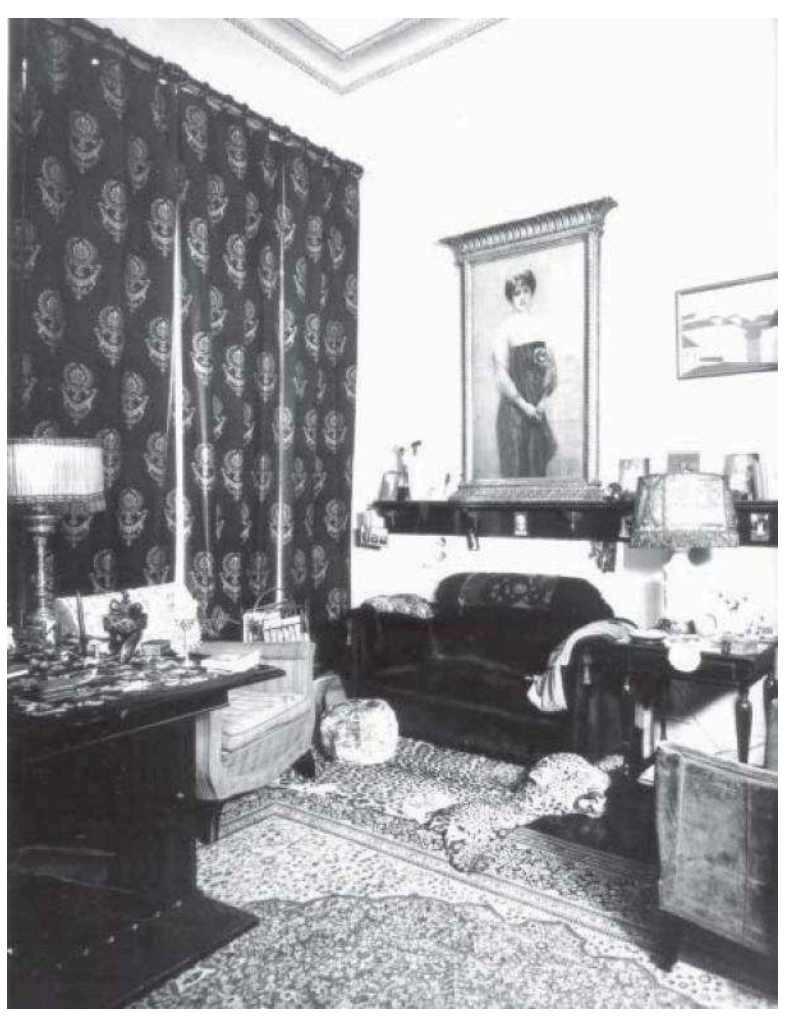

Os acontecimentos em questão vêm carregados de significação histórica e política. As elites paulistas, afastadas do poder após 1930, vêem nas novas eleições uma oportunidade de retorno. Depois de terem lutado contra a ditadura em 1932, lançam-se na conquista do voto e, principalmente, desejam deixar a marca de seus interesses nas páginas da nova Constituição. Interesses que visam sobretudo o estabelecimento de limites à ação do poder central, em favor dos estados, e uma política econômica favorável à cafeicultura.

Os resultados do pleito comprovam e ampliam tal significação. Em 1933, São Paulo será o único estado da federação a vencer o interventor varguista, ainda que este conte com a máquina oficial para promover o novo Partido da Lavoura. Dos 22 membros da bancada paulista, a Chapa Única elege 17 nomes (contra 2 do Partido da Lavoura e 3 do PSB). A partir de 1934, Carlota participa de uma bancada maior, de 34 cadeiras, dividida entre o Partido Constitucionalista e o PRP. 0 primeiro conta com 22 representantes; o segundo, com 12.

A entrada de Carlota neste espaço tão masculino da política foi o resultado de uma complexa combinatória de fatores que, juntos, jogaram a seu favor. E a amizade que 
mantinha com Olivia Guedes Penteado, que nos interessa particularmente aqui, ilumina tal percurso e é por ele simultaneamente iluminada. Porcurarei então, a seguir, recuperar os passos, ações e situações em que a mobilização feminina e, especificamente, aquela de D. Olivia, se cruzam com o contexto político-eleitoral envolvendo encontro singular de Carlota Pereira de Queiroz com as instâncias decisórias dos rumos da Nação.

No dia 9 de julho de 1932, eclode em São Paulo a Revolução Constitucionalista. A mobilização dos paulistas é intensa e não se restringe às elites. As mulheres encontram, nesse processo generalizado de adesão, formas de intervenção social que ultrapassam as possibilidades ordinariamente existentes. Em estado de guerra, elas têm álibis mais eficientes para o exercício da cidadania. Quanto às mulheres da elite, tal possibilidade foi particularmente explorada. A coesão em torno dos princípios que marcam a oposição radical dos paulistas a Vargas é algo profundamente vivido por mães, esposas e filhas das famílias do grupo, em todas as faixas etárias.

No início dos anos trinta, estas mulheres precisam, mais do que as outras, de razões fortes para exercerem atividades públicas e circularem livremente no espaço público. Algumas seguem carreiras, exercem atividades artísticas ou intelectuais, enfim, possuem responsabilidades que não se limitam ao mundo privado e familiar, mesmo se um tabu envolve a questão da remuneração, que aparece como secundária e não é sempre garantida. Mas num período em que toda a assistência social depende da benemerência, sem que exista qualquer regulamentação profissional ou ação estruturada por parte dos poderes públicos, as atividades filantrópicas representam, sem sombra de dúvidas, uma possibilidade privilegiada para a intervenção social das mulheres das camadas dominantes.

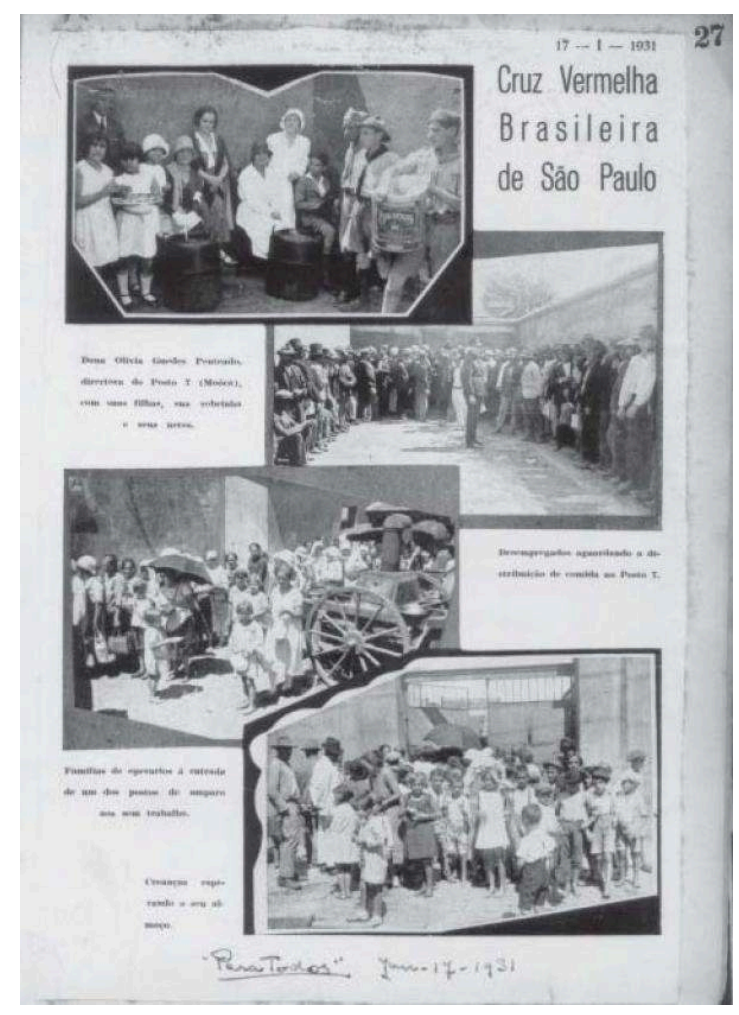




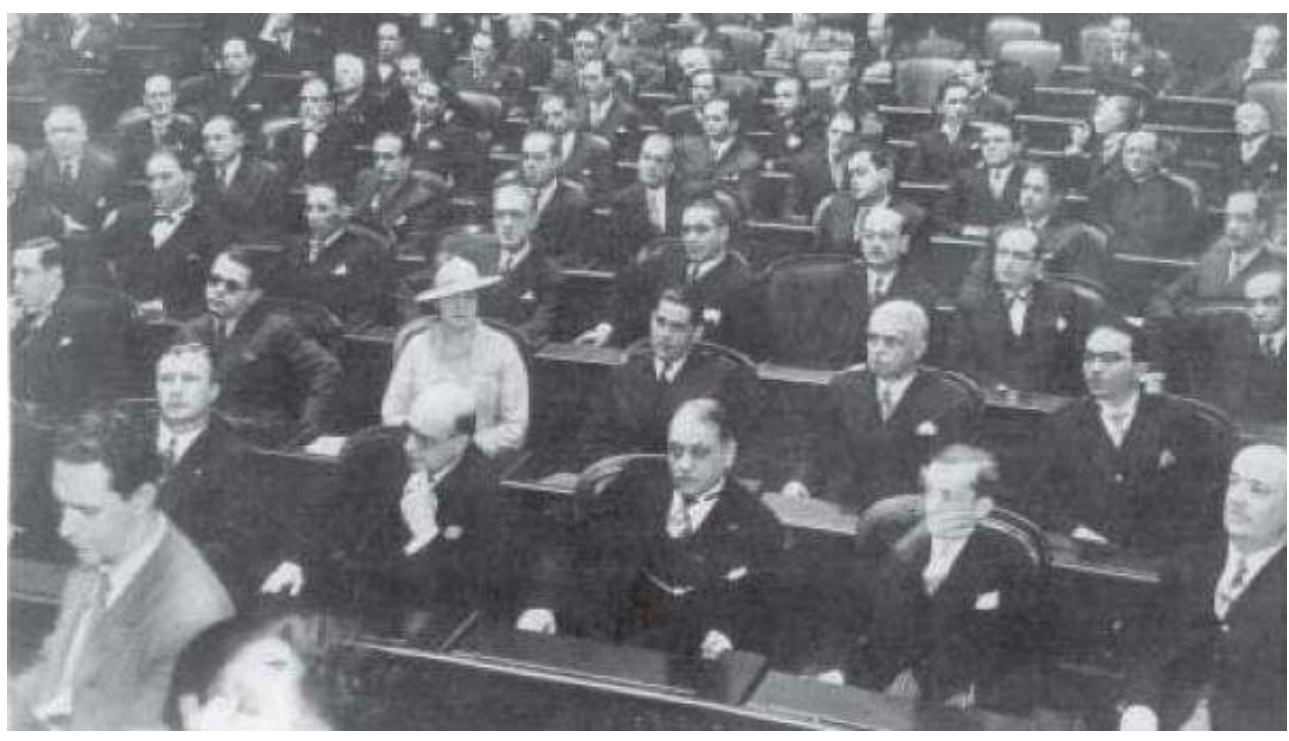

A duração imprevista da Revolução de 32 (quase três meses), onde os paulistas acabaram lutando sozinhos contra o governo central, improvisando forças e munições, abre às mulheres das elites uma chance única de exercício intensivo da cidadania ${ }^{9}$. Algumas organizações laicas ligadas à Igreja, como a Liga das Senhoras Católicas, exercem aí um papel de destaque. Reunindo um número considerável de mulheres em torno de ações bastante variadas, a Liga torna-se um eixo central para a organização e a mobilização femininas em 1932. Mas com os combates, as necessidades de assistência ultrapassam a ação regular da Liga e de suas congêneres. A cidade torna-se o palco onde desfilam rápidas e ocupadas mulheres das melhores famílias locais, de todas as idades, imbuídas da nobre missão de colaborar com o esforço revolucionário.

Diversos espaços e estruturas urbanas são oferecidos às organizadoras desse esforço cívico, onde funcionam ateliês de costura, de recebimento, seleção e empacotamento de tudo aquilo que possa trazer conforto físico e espiritual aos soldados paulistas.

Se na memória dos homens que lutaram por São Paulo, a Revolução Constitucionalista segue sendo um tema de grande destaque, nos depoimentos das mulheres das elites, o circuito criado na cidade em torno da ajuda aos soldados é elemento central:

Mas naquele tempo todas nós trabalhamos desesperadamente, só com aquele fito da Revolução, que ficou para nós, brasileiras, mulheres brasileiras... foi uma coisa que marcou a vida de todas nós.

(...)

Era um lugar que fazia paçoca, fazia uns cartuchos de paçoca, pra mandar pros soldados na frente, então enchia esses cartuchos de paçoca, e tal, mandava aqueles caminhões (...) e depois, trabalhava na Liga das Senhoras Católicas, lá, trabalhei muito lá. Aí ia buscar costura, era na rua Líbero Badaró, pra mamãe fazer lá em casa dela, e nós fazíamos tricô, (...) fazia aqueles capuzes pros soldados lá na frente, suéters, cachecóis, todas essas coisas, não é ? E trabalhávamos também lá no Trianon, na avenida Paulista. A paçoca eu acho que era aqui, era perto do Teatro Municipal, ali na casa do Samuel Alves Vieira, ele ofereceu, e tinha uma paçoca ali na avenida Paulista, no Trianon... ${ }^{10}$

Eu tinha oito anos... o lugar onde se trabalhava pra Revolução era naquele antigo cinema República, na praça da República (...) era um salão enorme, eu e minhas irmãs, tinha uma irmã que é mais velha que eu um ano, íamos lá para enrolar atadura, passávamos a tarde inteira enrolando atadura... que é uma coisa, eu acho, extraordinária... ${ }^{11}$ 
Num espaço urbano muito mais masculino que misto, onde as mulheres, principalmente de elite, são presença estrangeira sob os olhares dos homens, muito mais familiarizados com a rua, poder circular entre diversos pontos, freqüentar espaços explicitamente abertos às mulheres é uma oportunidade ainda inédita, ou ao menos extremamente $\operatorname{rara}^{12}$. E, além disso, tal freqüentação apresenta objetivos nobres, cívicos, e abre a essas mulheres a ocasião de realmente trabalhar, para utilizar o termo tantas vezes empregado nos depoimentos.

39 A cidade se transforma então, provisoriamente, criando uma dinâmica urbana que vive pela e para a Revolução, com circuitos e locais reservados às necessidades da rebelião. Se pensarmos na planta de São Paulo, com seus espaços e eixos de referência, histórica ou outra, podemos dizer que os locais e circuitos que se abrem à mobilização da retaguarda constitucionalista ocupam pontos capitais da cidade - o cinema República, o Trianon, etc. Criam-se, assim, os postos de assistência mais variados como o Posto do Cigarro, o Lunch Expresso, a Cruzada do Ovo, o Meias para os Soldados, a Cruzada dos Capuzes de Lã, a Casa da Formiga (para vestir filhos de combatentes), etc. Além deste ajustamento entre um evento que se torna central na vida dos cidadãos e a sua vinda ao primeiro plano na dinâmica espacial urbana, a novidade está em que as mulheres são agentes da constituição mesma de tais circuitos, e da transformação funcional por que passam os espaços abertos à sua ação - de cinema a centro de empacotamento, de espaço de reuniões sociais a ateliê de costura e fabricação de uniformes, sem contar enfermarias, hospitais e outros. Na repartição entre os campos feminino e masculino de ação, elas ocupam seu espaço e exercem aí atividades de grande importância para os rebeldes, em nada frívolas ou acessórias.

O primeiro organismo criado para dar assistência aos soldados da Revolução (uniformes, equipamentos, alimentação) recebe simbolicamente o nome de MMDC e está na origem do Departamento dos Serviços Auxiliares de Guerra, ao qual se subordinam o Departamento de Assistência à População Civil, dirigido por Olivia Guedes Penteado, e os Serviços Auxiliares de Saúde. Deste último sairá, em 18 de agosto, o DAF - Departamento de Assistência aos Feridos - organizado e dirigido por Carlota Pereira de Queiroz, Maria Guedes Penteado de Camargo e Lucia Burchard Revoredo. Antes disso, já mobilizada, Carlota dirigira a oficina de costura da Cruz Vermelha, especializada em roupas hospitalares, ao lado de Carolina da Silva Telles e Lucia Burchard Revoredo ${ }^{13}$. Fundada em 16 de julho, esta oficina foi o primeiro contato de Carlota com a rede hospitalar de urgência que se organiza em torno à Revolução.

41 A atuação de Carlota não se limitou à direção destes dois organismos. Inserida numa complexa e ativa rede de assistência, seu nome circula em outras tantas iniciativas e manifestações, seja por intermédio das trocas, das doações e dos pedidos realizados entre a oficina da Cruz Vermelha, o DAF e outras organizações, seja como colaboradora de outros projetos, tais como a Cruzada Artística ou a Campanha do Ouro. Além disso, ela também exerceu a medicina, trabalhou em hospitais e colocou doentes em alguns deles num momento em que vagas e leitos eram deficitários. Mantendo relações com os membros mobilizados das elites, trocando serviços e favores, e auxiliando aqueles que pedem assistência, Carlota ocupa um espaço de destaque e não somente em meio às mulheres, pois nem todos os homens estão no front, muitos gerem, dirigem e organizam a guerra de outro modo, junto às mulheres.

A presença de Carlota neste circuito é mais complexa do que a das demais voluntárias. Pois ela tem sua carreira: é educadora desde 1909 e médica desde 1926. Sua entrada na 
esfera pública de atividades não depende de sua ação filantrópica, este não é um álibi para que tenha acesso a responsabilidades alternativas ao lar, como acredito ser uma das principais razões, senão a primeira, para explicar a ação intensiva de muitas mulheres das elites da época nas redes da benemerência. Além disso, a idade é um elemento libertador para uma mulher de seu meio social. Em 1932, Carlota tem 40 anos e permanece solteira o que lhe garante, em relação às moças em idade de casar, ou às casadas, uma maior autonomia de movimento, deslocamento e ação. Apesar de nivelarse mais, em idade, com as filhas de D. Olivia, equipara-se mais a esta, então com 60 anos e viúva há quase 20 , quanto à sua independência. Nenhuma das duas necessita de álibis para ir à cidade.

Eis como sua atuação junto ao DAF mistura os trunfos dados pelo diploma médico, cujo significado social ela não ignora, às formas tradicionais de ação feminina:

Certa de que, como medica, meus serviços não valeriam os de um profissional, pela falta da pratica cirurgica, indispensavel nos campos de batalha, resolvi permanecer em São Paulo, onde a minha situação social me permittia aproveitar a bôa vontade de centenas e centenas de senhoras que desejavam e precisavam trabalhar.

(...)

...algumas semanas decorridas, começavam a chegar a São Paulo os primeiros feridos. E, a mulher paulista, impossibilitada muitas vezes de ir até a trincheira, queria ao menos dar-lhes um pouco do seu carinho e da sua sympathia. Foi quando se instalou o D.A.F. (Departamento de Assistencia aos Feridos), que também dirigi.

Creado por iniciativa particular e mantido por donativos, surgiu do nada e foi uma instituição.

Era um agrupamento de cem senhoras, que se incubiram da assistencia moral e material dos feridos, individualmente.

Tendo entrada em todos os hospitaes de sangue, ellas se dividiam em turmas e serviam ora num, ora noutro, de accôrdo com as horas designadas.

(...)

Eis ahi porque me orgulho de ter sido apontada para representante da mulher paulista $^{14}$, cuja grandeza dalma senti desde o primeiro momento, na espontaneidade com que ella se chegava ao meu nome de medica, para ter entrada nos hospitaes. ${ }^{15}$ pela Revolução, ao criar e dirigir o DAF Carlota não se limita a prestar assistência e socorro médico às vítimas da Revolução. Ela aproxima-se dos líderes da Revolução e afirma, pelo seu engajamento nada discreto, um acordo profundo com os ideais das elites paulistas em luta contra Vargas. Trata-se de um verdadeiro comprometimento político.

Carlota participa ativamente da Revolução Constitucionalista sabendo que o novo contexto político, que afastou do poder as elites paulistas em 1930, trouxe novidades às mulheres. Novidades que lhes tinham sido negadas durante todo o período republicano anterior, quando esse mesmo grupo deteve o poder: o direito de voto e de elegibilidade ${ }^{16}$. Paradoxalmente, Carlota pôde se apresentar como candidata, e elegerse, graças às novas regras instituídas por Getúlio, a quem fará oposição política junto àqueles pelos quais sua fidelidade será incondicinal - como já o fora em 32 . 
A Diretoria do DAF - Departamento de Assistência aos Feridos durante a Revolução Constitucionalista em 1932

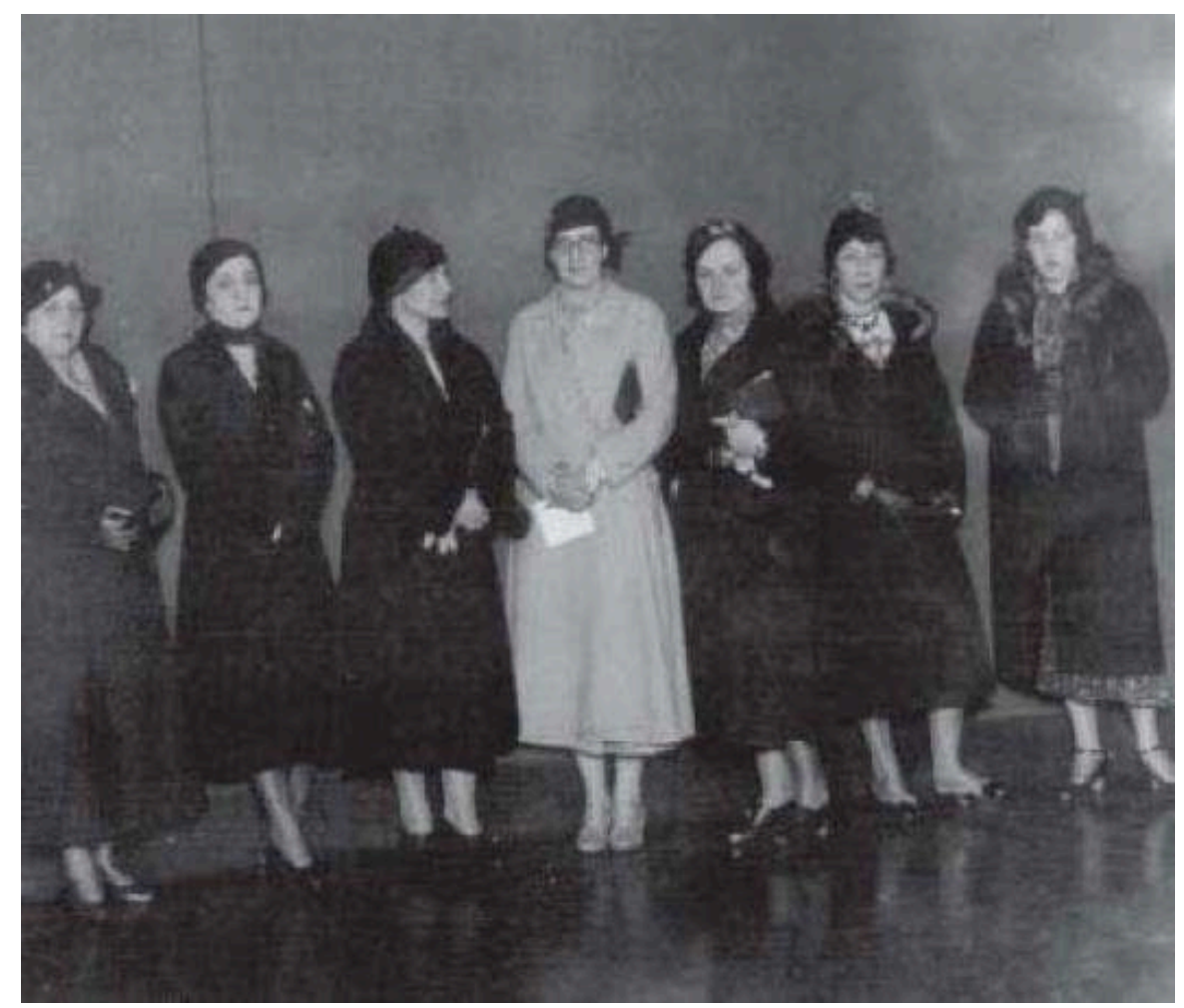

Da esquerda para a direita: D. Lena Burchard Reverdo, D. Lú Buchard Reverdo, D. Olivia Guedes Penteado, Dra. Carlota Pereira de Queiroz, D. Maria Penteado Camargo (filha de D. Olivia) e mais duas senhoras não identificadas.

Chegado o momento eleitoral, a oposição a Vargas e a perspectiva de retorno ao poder reúnem de maneira eficaz as diferentes facções políticas das elites locais, num contexto marcado pelo regionalismo. O clima é de exploração intensiva da imagem do Bandeirante, recuperada pelas elites do café, e usada, nos anos 1920 e 1930, para explicar o sucesso da cafeicultura, o enriquecimento do grupo e a expansão rumo ao Oeste como sendo conseqüências naturais de uma herança. No período pré-eleitoral, as referências constantes à bravura e à força dos pioneiros paulistas, "herdeiros" dos bandeirantes, transformam-nos mais uma vez em vanguarda nacional, pela luta solitária que travaram, em 1932, pelos princípios democráticos.

Surge então a "Chapa Única por São Paulo Unido !", cujos 22 candidatos são escolhidos da seguinte maneira: uma comissão de cinco membros, dita Comissão dos Cinco, representa as cinco organizações que compõem a frente criada- a Associação Comercial, a Liga Eleitoral Católica (LEC), a Federação dos Voluntários (da Revolução de 32), o PRP e o PD. Cada representante da comissão apresenta uma lista com dez nomes e, do conjunto de cinqüenta candidatos propostos, são escolhidos os definitivos.

A inclusão de Carlota entre os candidatos da Chapa dá-se, em primeiro lugar, através da lista da Associação Comercial que recebe sugestões, entre outros, da recém-fundada Associação Cívica Feminina (ACF). Esta, de cujo Conselho Carlota faz parte, realiza sessão extraordinária no dia 30 de março de 1933 e apresenta sua candidatura, defendendo assim a idéia de que uma representante feminina deve integrar a Chapa 
Única. Além dessa indicação, outras treze associações femininas vêm reforçar o mesmo raciocínio ${ }^{17}$.

49

A ACF, particularmente ativa no contexto pré-eleitoral paulista é idealizada e dirigida, desde a primeira gestão, por um grupo de mulheres muito próximas a Carlota, a começar por sua diretora, Olivia Guedes Penteado, passando pelas conselheiras Guiomar Novaes Pinto e Nair Mesquita e, dentre as sócias-fundadoras, pelas também amigas Pérola Byington e Luiza Gama Cerqueira de Carvalho, que redige os estatutos da organização. Após a fundação, institui-se também um Conselho Masculino, com nomes conhecidos. Figuram aí alguns dos futuros companheiros de bancada de Carlota, como Carlos de Moraes Andrade e José Carlos de Macedo Soares, sendo este útimo diretor de destaque da Associação Comercial.

A segunda indicação do nome de Carlota à Comissão dos Cinco deve-se à Federação dos Voluntários, nova força política do Estado ${ }^{18}$.

51 Assim, os principais apoios recebidos por Carlota vêm, de um lado, das novas expressões políticas emergentes e, de outro, das lideranças femininas. Algumas vezes, os dois vetores se cruzam, como é o caso da ACF que, feminina, é fruto da mobilização cívica de 1932.

Uma vez formalizada sua candidatura, Carlota volta-se ao eleitorado feminino que poderá, pela primeira vez na história brasileira, manifestar-se nas urnas em nível nacional. Mesmo se as mulheres não têm obrigação de fazê-lo, o que muda tudo: elas têm, espontaneamente, que se alistar antes do pleito, caso tenham vontade de participar. Assim, as organizadoras da campanha de Carlota utilizam-se da rede estruturada da qual dispõem, de associações feministas, femininas e beneméritas, para divulgar a sua candidatura e para informar as mulheres sobre a necessidade do alistamento eleitoral. No Rio, as feministas organizadas em torno da Federação Brasileira pelo Progresso Feminino (FBPF), dirigida por Bertha Lutz, trabalham muito neste sentido e Bertha dá conselhos a Carlota, em suas cartas, sobre a estratégia que deve adotar a ACF. As líderes dessa mobilização sabem que aquelas que não tiverem seu título de eleitor não poderão votar; o alistamento é, aliás, um dos grandes motores da criação da ACF. 
Homenagem prestada a D. Olivia Guedes Penteado pela Associação Cívica Feminina, em 18 de maio. $O$ Estado de São Paulo, 14, julho, 1933

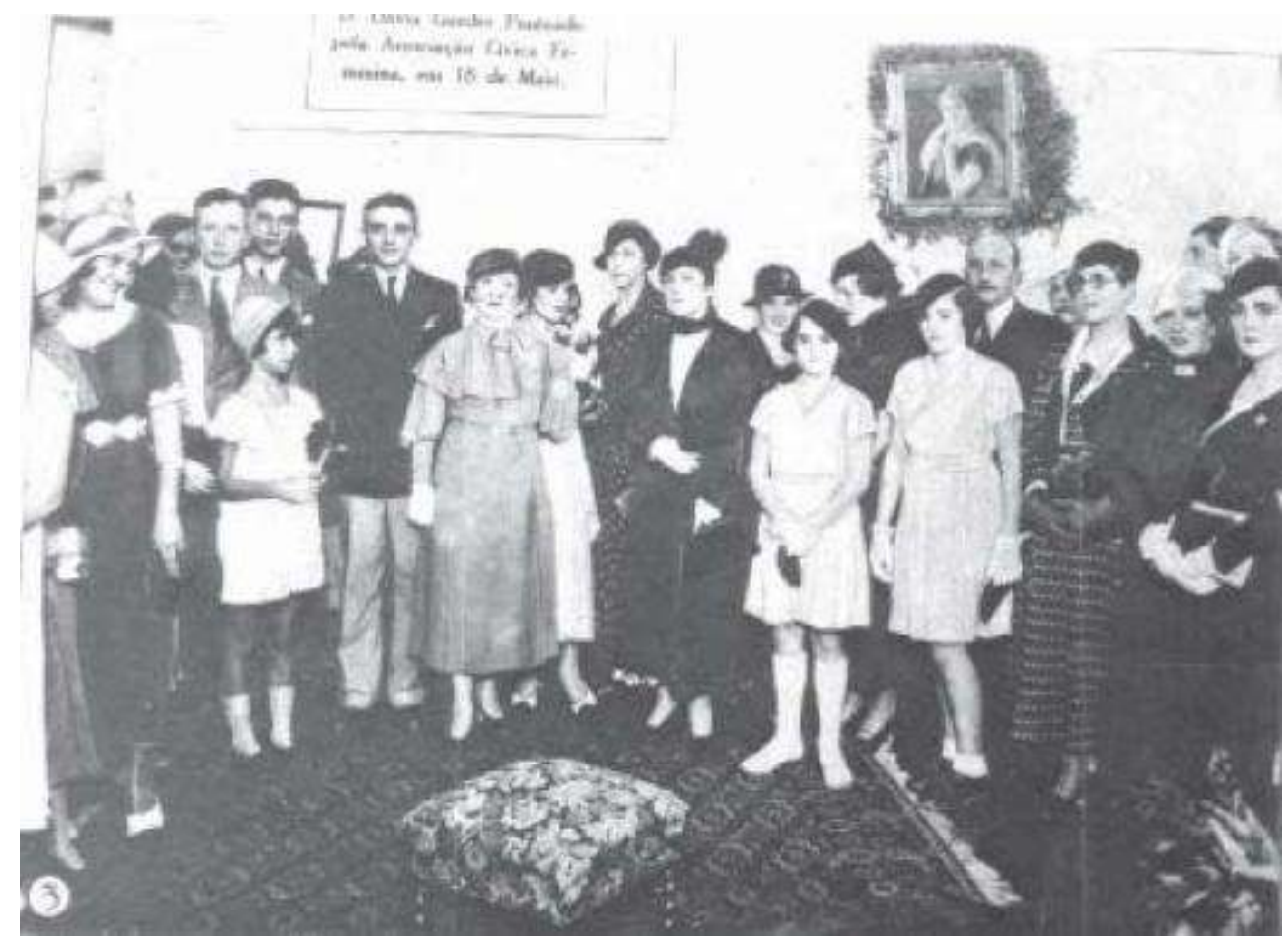

53 A Liga das Senhoras Católicas, como a ACF, organizam pontos de alistamento eleitoral espalhados pela cidade. A Igreja, tendo apoiado oficialmente a Revolução de 32, faz parte das forças que compõem a Chapa Única, através da LEC. A Liga das Senhoras Católicas mobiliza-se intensamente no momento pré-eleitoral, consciente do potencial do eleitorado feminino, novo, para apoiar candidatos que representem as reivindicações católicas junto à Chapa Única e na Constituinte. Suas dirigentes discursam, vão às radios, chamam as católicas a se alistarem e a votarem, a exercerem aquilo que, em suas falas, católicas, de um direito passa a ser um dever das cidadãs. Seu prestígio e atuação são reconhecidos e a ACF procura uma aliança que se formalizará: a Liga reúne em sua sede, no dia 17 de abril, 19 associações femininas ${ }^{19}$, às quais se associa, para compor a União Feminina Paulista, voltada para a propaganda em pról da frente de oposição paulista. Se a Liga não fala diretamente no nome de Carlota, e se esta não é nem mesmo uma candidata indicada pela LEC, ela é reconhecidamente católica e a mobilização de todas essas associações e mulheres joga a seu favor. Sem contar que, dentre as sócias e dirigentes da Liga, ela conta com muitas amigas e conhecidas, a começar por Dona Olivia e Perola Byington, além de tantas outras, amigas, conhecidas, parentes mais ou menos próximas, sobretudo pelo lado materno (ela mesma só figura nas listas de sócias após sua eleição, a partir do biênio 1934-36). As listas de adesão e de direção da Liga, da ACF e da União Feminina Paulista apresentam várias intersecções, mas não se sobrepõem, abrindo para Carlota e seu grupo inúmeras possibilidades de apoio, já que todas circulam bem nesta vasta rede de organizações, possuindo aí diversas interlocutoras simpáticas à sua causa.

O espaço ocupado por Carlota na Constituinte e na Câmara Federal é algo inédito para uma mulher, carregado de um grande valor simbólico. Para as feministas, os anos 1932-33 têm uma importância toda particular. Se, em 1932, com a inclusão do voto feminino na nova Lei Eleitoral, elas vêem concretizada mais de uma década de lutas, 
inicia-se aí uma nova fase de composições, de compromissos e arranjos. O novo objetivo é levar à Constituinte alguns nomes femininos, a seus olhos representativos dos interesses feministas, para deixar impressas na nova Carta Constitucional algumas das melhorias que reivindicam.

Agindo no Rio, Bertha Lutz e suas correligionárias esforçam-se por mobilizar ao máximo seus contatos políticos, não somente para manterem-se informadas dos bastidores da política, como também para negociarem seu espaço. Elas entram então em contato com alguns nomes de destaque da sociedade paulista, ainda marcada pelo esforço cívico feminino de 1932. E Carlota toma parte na liderança de toda e qualquer mobilização cívico-política das mulheres paulistas que se segue à Revolução.

O tom geral das cartas de Bertha para Carlota é amigável, indicando uma relação próxima $^{20}$ e preocupações comuns que, em alguns casos, se concretizam no envolvimento de ambas num mesmo projeto - como o da criação de um Museu da Infância, em São Paulo, que reúne os fortes interesses das duas pela questão da Infância. Porém, no contexto privilegiado de 1932-33, as preocupações políticas tomam a dianteira em relação a qualquer outro tema, tanto para Bertha, quanto para Carlota, cada uma a seu modo. Daí o interesse de Bertha pela evolução dos acontecimentos em São Paulo. A fundação da ACF, em dezembro de 1932, parece-lhe a via certa para um trabalho conjunto. Assim, em carta datada de 30 de janeiro de 1933, ela lança propostas precisas no sentido de uma real colaboração entre a FBPF e a ACF. Consciente da força do regionalismo reinante em São Paulo, chega a dizer que as ativistas dos dois estados seriam paulistas: ela - nascida em São Paulo -, trabalharia no Rio, e Helena Gordo, seu contato em São Paulo, trabalharia junto à própria Carlota e a D. Olivia (“d. O.”). A seu ver, o trabalho consistiria numa campanha de educação cívico-política da mulher, e na realização da tarefa prática e urgente de organizar o alistamento:

...acho bom fazer alistamento "para a defesa da criança e da mulher" - o que a ninguem assustará. (Bertha Lutz, carta a Carlota Pereira de Queiroz, 30 de janeiro de 1933)

Bertha é uma observadora atenta dos rumos da política e da movimentação em torno das futuras eleições. Assim, vendo no trabalho com a ACF uma possibilidade real de concretização dos ideais que defende, está consciente de que a Associação das paulistas é o resultado de uma mobilização política significativa e que Carlota é aí um nomechave. Nesse contexto, em fevereiro ela vai a São Paulo e é recebida por Carlota, que lhe organiza encontros com as lideranças femininas da cidade. Estas oferecem-lhe uma bandeira de São Paulo ${ }^{21}$. Em duas cartas escritas após sua volta ao Rio, Bertha mostra-se extremamente agradecida e entusiasmada:

Minha Querida Carlota

Tencionava escrever uma carta longa e nella expandir-me longamente, sobre a impressão magnifica de dynamismo e elevação idealista, que trouxe da nossa terra, da sua mocidade e da sua população feminina, á qual cabe hoje o papel de reconstructora da vida nacional

Quizera dizer tambem mais uma vez a impressão profunda que trouxe da leaderança da A.C.F. e da presidente, alma feminina de raro escól ${ }^{22}$. Era egualmente meu plano incluir um cartãozinho de agradecimentos a todas as que assignaram a lista e me offereceram o symbolo pelo qual unida trabalharei com vocês todas, sem desfallecimentos e sem medir sacrificios.

Disponham de mim.

(...) 
Nunca tive a honra e a alegria de ser tão bem cuidada, como nas suas mãos, e de encontrar uma tarefa tão suavisada, como a minha pela presença de um cerebro, uma inteligencia e uma amisade egual as suas. (Bertha Lutz, carta a Carlota Pereira de Queiroz, 15 de fevereiro de 1933)

Como vae ? Eu tenho sentido muitas saudades suas e você tem me feito muita falta, não só pela gentilesa com que você se dedicou inteiramente á minha pessoa, o que em si ja me teria tornado muito grata, mas principalmente pela grande satisfação de ter numa creatura amiga, um cerebro de escol e uma personalidade, sympathica, leal, forte e aguerida, permitindo avaliar e pesar actos, factos e pessoas e estabelecer orientações e directrizes. (Bertha Lutz, carta a Carlota Pereira de Queiroz, 19 de fevereiro de 1933)

Quanto à questão das eleições, é preciso lembrar que, devido ao levante de 1932, a participação de São Paulo na Constituinte fica comprometida até janeiro de 1933, quando acaba sendo confirmada por resolução do Superior Tribunal de Justiça. Assim, as negociações só se efetivam pouco antes do escrutínio: o Partido da Lavoura é criado em março e a aliança PRP-PD efetiva-se no final do mesmo mês sendo tomada, logo em seguida, a decisão de reunir as forças paulistas de oposição em torno de uma frente única. Logo que a iniciativa se concretiza e que todos se mobilizam em torno da composição da Chapa Única, Bertha telegrafa a Carlota:

Essencial associações femininas todo estado consigam uma vaga candidatura feminina conchavos abraços Bertha. (Bertha Lutz, telegrama a Carlota Pereira de Queiroz, 25 de março de 1933) ${ }^{23}$

Automóvel Club, banquete oferecido por D. Olivia Guedes Penteado e suas filhas a Dra. Carlota Pereira de Queiroz. 1933

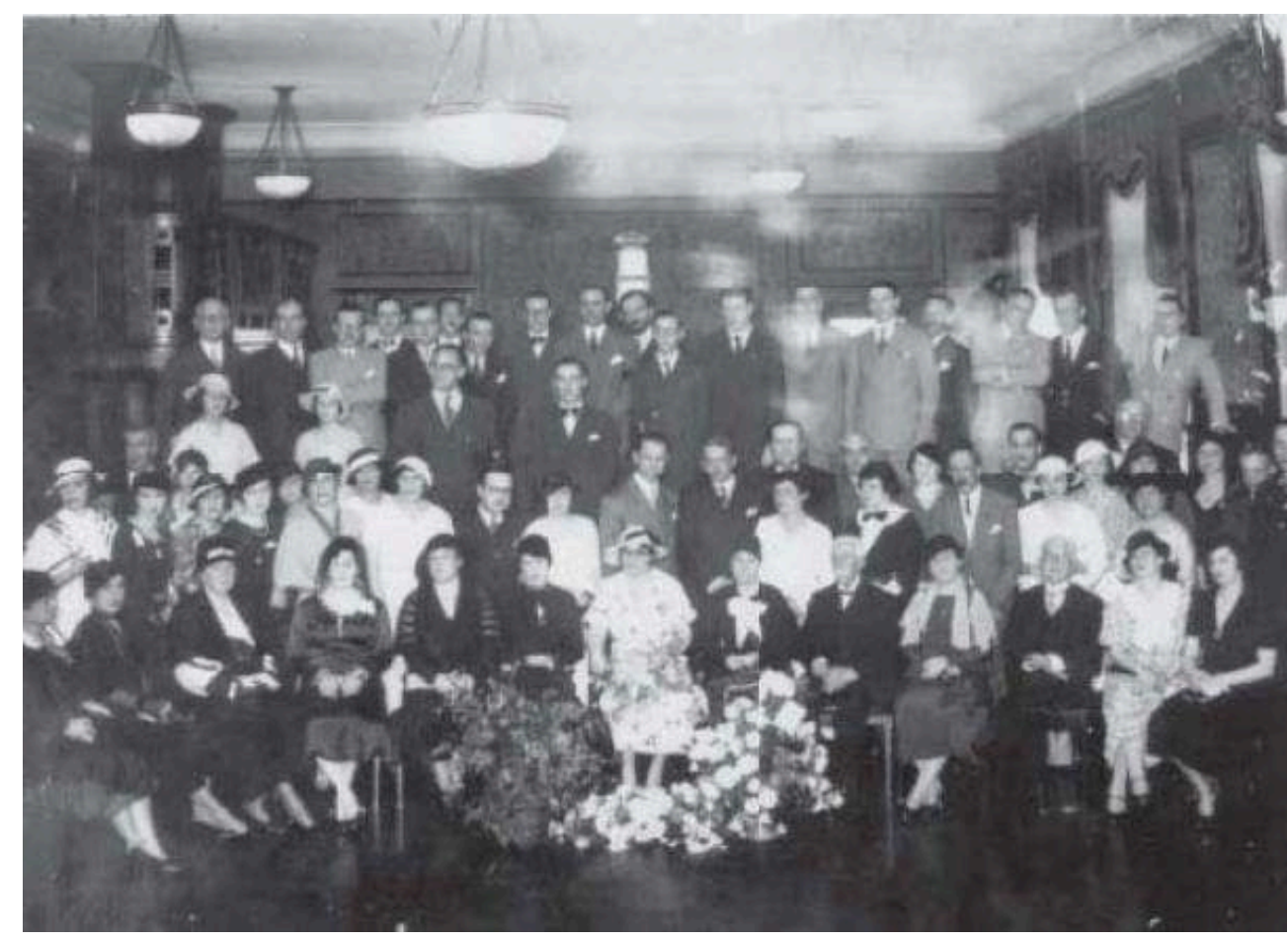

Quanto aos "conchavos", não sabemos se o nome de Carlota já está sendo cogitado entre as lideranças femininas antes de ser lançado pela ACF. Faltam documentos sobre as negociações em São Paulo, onde Carlota Pereira de Queiroz, Olivia Penteado e outras podem encontrar-se pessoalmente, falar por telefone, sem necessitarem do recurso às cartas. 
60 Mas o nome de Carlota vai ganhando força, contando com a mobilização de um bom número de mulheres de prestígio, realmente dispostas a ver uma representante feminina sentar-se na Constituinte. Dois acontecimentos serão cruciais para a definição de sua candidatura.

Banquete comemorativo pelo lançamento da candidatura da Dra. Carlota Pereira de Queiroz à Assembléia Constituinte em 1933, organizado por amigos e admiradores

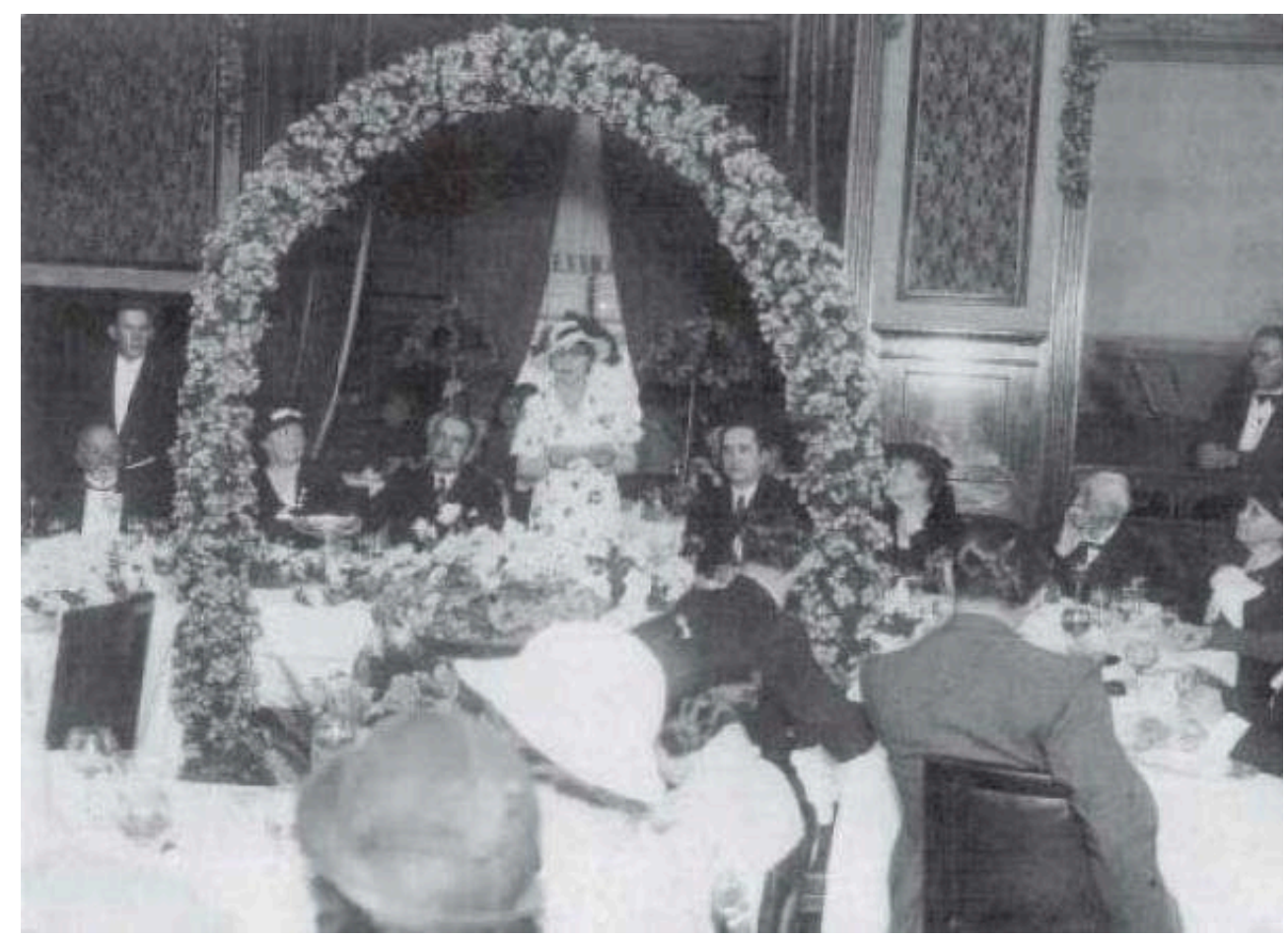

Da esquerda para a direita: D. Pérola Byington, Prof. Antonio Alcantara Machado, Dra. Carlota (discursando), Dr. Antonio Cintra Gordinho, D. Olivia Guedes Penteado e o casal Condes José Vicente de Azevedo.

61 Em primeiro lugar, um plebiscito lançado pelo Diário da Noite pede à população que indique suas preferências para a escolha dos integrantes da Chapa Única. Fato no mínimo curioso, pois o mecanismo utilizado pela coalizão dos "paulistas" para a escolha dos candidatos não previa, como vimos, qualquer consulta à população. Em todo o caso, a iniciativa dos Diários Associados permite que, na edição de 3 de abril, apresentando resultados ainda parciais, o jornal publique um artigo de primeira página intitulado "Dra. Carlota Pereira de Queiroz" e, em tipos menores, "O voto de dona Olivia Guedes Penteado, lembrando o nome da illustre senhora paulista, como candidata do eleitorado feminino". A foto é de dona Olivia e o jornal abre seu artigo falando do voto dessa outra "ilustre senhora paulista". Segundo o periódico, o nome de Carlota "está reunindo (...) o maior numero de sympathias do eleitorado feminino de S. Paulo". Segue-se uma pequena biografia, muito elogiosa, resumindo principalmente seu itinerário profissional ${ }^{24}$. Ora, o apoio da amiga Olivia Guedes Penteado, é certamente capital para a conquista de um espaço tão concorrido como o dos 22 nomes da Chapa Única. Mas junta-se a isso o próprio prestígio de Carlota, que ocupa cada vez mais a cena política: na "Campanha pelo voto", feita pelo mesmo Diário da Noite, ela é chamada a se pronunciar e, a 30 de março, faz um discurso, transmitido pelo "Jornal Falado" dos Diários Associados e transcrito nas páginas do jornal. Sob a foto estampada, Carlota 
chama os - e as - paulistas a votarem pelos ideais de $1932^{25}$. Um tal apelo não só reforça os contornos de sua identidade pública e de sua filiação política, mas surte certamente seus efeitos, numa conjuntura marcada pelas expressões de civismo e de regionalismo.

O segundo acontecimento ocorre no dia 8 de abril, três dias antes da divulgação oficial dos candidatos da Chapa Única. Um passo decisivo é dado então pelas articuladoras da campanha de Carlota - especialmente Olivia Guedes Penteado e Pérola Byngton. Nessa ocasião, seu nome já constando das listas entregues pela Associação Comercial e pela Federação dos Voluntários à Comissão dos Cinco, elas decidem lançá-lo publicamente. $O$ Estado de S. Paulo publica assim um manifesto intitulado "Mensagem da Mulher Paulista", que começa dizendo:

Pedem-nos a publicação da seguinte mensagem aos organisadores da chapa unica e ao eleitorado de São Paulo

Segue-se um elogio à consciência cívica da "mulher paulista", fato verificado graças à mobilização em torno do alistamento eleitoral. Porém, tendo em vista seu passado e sua atuação em 1932, é preciso também, segundo as autoras do texto, que esta "mulher paulista" possa participar diretamente dos trabalhos da Constituinte. É assim que, para a representação feminina de São Paulo, propõem o nome de Carlota Pereira de Queiroz. Vem enfim, mais uma vez, um texto biográfico com o resumo de seu itinerário profissional, cheio de louvores, e 65 assinaturas de apoio, encabeçadas pela de D. Olivia ${ }^{26}$.

Encontra-se lançada a candidatura de Carlota Pereira de Queiroz. Tendo viajado ao Rio para assistir a uma convenção organizada pela FBPF (para a qual Bertha convida com insistência Carlota e seu grupo), Luizita Gama Cerqueira de Carvalho, a única delas que responde ao convite, escreve uma carta à amiga. Dentre outras coisas, ela nos informa sobre a determinação do grupo de mulheres envolvido e das pressões e "conchavos" dos quais foram capazes para inserir sua representante no conchavo maior:

[Bertha Lutz] É da mesma opinião que D. Olivia: ou nenhum candidato, ou apenas um nome feminino. (Luizita Gama Cerqueira de Carvalho, carta a Carlota Pereira de Queiroz, 5 de abril de 1933)

Daí em diante, Carlota começa a tomar cada vez mais a palavra e a tornar públicas suas idéias e posições, dirigindo-se aos eleitores e, principalmente, às eleitoras. Vem então à tona um conflito que aparentemente surpreende as feministas. Pouco antes das eleições, uma nova carta de Bertha aborda pela primeira vez a questão:

Como vae ahí de propaganda e de resultado. Sei que sua vitoria é certa e fico muito satisfeita com isso. Espero entretanto que você dê apoio ao programma feminista, não é assim.

Ainda não li a entrevista que você deu, mas soube que você teve a gentilesa de falar em mim. Algumas ficaram um pouco sentidas, por você não se ter declarado feminista, porque para nós a entrada da mulher na Constituinte representa o resultado de 14 annos de luta. (...) e afinal o que se precisa é defesa da Mulher.

Mas eu, tenho certesa que você sera um baluarte feminista, não é assim ?

Tenho o dito aqui á imprensa com moderação, ás collegas com enthusiasmo. Tenho recebido applausos á minha candidatura de S. Paulo e tenho pedido a todos que votem em você, já que o enthusiasmo delles deve beneficiar uma mulher. (Bertha Lutz, carta a Carlota Pereira de Queiroz, s/d)

Fica difícil datar exatamente essa carta, pois Bertha faz referência, no início, a uma longa carta e a um telegrama que teria enviado antes a Carlota, e estes não foram localizados. Apesar disso, diz que contava, em ambos, não ter podido "ir à estação ver Luisita". Luizita, ao que sabemos, esteve no Rio no início de abril. Quanto à entrevista 
da qual fala Bertha, também não foi possível encontrá-la, pois se existem algumas dessa época, nenhuma faz referência a ela. Uma coisa é certa: a partir do momento em que o nome de Carlota é lançado - e sobretudo depois de ser oficialmente anunciado pela Comissão dos Cinco -, sua voz começa a ser mais solicitada pela imprensa e ela produz inúmeros textos (discursos, entrevistas, depoimentos). Nestes, explicando e justificando sua candidatura e, mais tarde, sua eleição, ela confirma as preocupações de Bertha e das demais feministas, expressas pela primeira vez na carta citada acima. Assim, a Folha da Noite publica, em sua edição de 12 de abril, as primeiras declarações de Carlota Pereira de Queiroz, oficialmente candidata desde a véspera. Apesar de não fazer aí nenhuma menção ao nome de Bertha, Carlota já define o que será para ela, até o final de sua carreira política, seu papel enquanto mulher e representante das mulheres:

A minha candidatura (...) não é senão uma nova conquista da mulher bandeirante. Mulher que vem atravessando, vencedora e gloriosa, esta jornada de civismo, que se iniciou a 9 de julho. E que tem evidenciado, em toda a sua pujança a sua abnegação, o seu heroismo, a energia de seus sentimentos; enfim, a tempera inquebrantavel, que a faz digna das tradições paulistas.

Sou depositaria dessa conquista - nada mais do que isso. Procurarei guardal-a, carinhosamente, para mais tarde, quando terminar minha missão, restituill-a á sua verdadeira dona - a mulher paulista.

$\mathrm{Na}$ Constituinte, espero, observarei diretrizes de interprete fiel de minhas patricias. 27

67 Como observam Bertha e suas companheiras, atentas aos pronunciamentos daquela que pensavam ser sua representante, Carlota não se apresenta, e nunca o fará, como feminista. Vem daí o desapontamento crescente das feministas, que podemos ler nas cartas de Bertha. Pois antes de identificar-se com as questões feministas, Carlota está empenhada em afirmar sua ligação privilegiada com o ideário constitucionalista de 1932 e sua cumplicidade principal com os "paulistas" e seus interesses.

As feministas, por sua vez, esperam dela um envolvimento explícito com a sua causa, para ver, na primeira deputada federal do país, integrante de uma Assembléia Nacional Constituinte, uma representante das idéias que defendem. Elas logo percebem que Carlota não pretende exercer tal papel. Sobre isso, cito uma última vez Bertha Lutz, já decepcionada, escrevendo a Carlota, já eleita:

\section{Carlota}

abraços

Recebi noticias de São Paulo, dos jornaes, mostrando o quanto você está sendo homenageada e como está fallando com eloquencia. Acompanho tudo com interesse vivo. Parabens.

Quando virá ao Rio ? Alem da representação preciosa da grande terra que é S. Paulo, você representará na Constituinte a população feminina de $44 \%$ do territorio sulamericano, que não elegeu outra mulher. E esta população muito em você confia e muito tem que lhe dizer.

Escreva-me, avisando sua vinda, sim?

Aqui os jornais têm explorado muito contra a mulher e o eleitorado feminino a sua declaração de que não é feminista, embora o resto das suas palavras desmintam essa declaração. Acham adoravel repetir que a unica mulher eleita é inimiga da mulher e não reconhece o esforço coletivo do sexo. Felizmente já estou calejada na luta. (Bertha Lutz, carta a Carlota Pereira de Queiroz, 31 de outubro de 1933)

Falando das homenagens feitas a Carlota e de sua eloqüência, Bertha poderia muito bem estar se referindo a um "Grande Banquete" oferecido à nova deputada por seus “amigos e admiradores", a 22 de outubro de 1933, em razão de sua eleição. A iniciativa cabe a D. Olivia e suas filhas, responsáveis, também, pela publicação que lhe é oferecida 
na ocasião, contendo o conjunto dos discursos feitos, a lista dos numerosos presentes e daqueles, mais numerosos ainda, que enviaram cartas, cartões e telegramas ${ }^{28}$.

Um acordo claro, festivo e vitorioso reúne o tom da fala de Carlota à de seus futuros colegas de bancada José de Almeida Camargo e José de Alcantara Machado, que também tomam a palavra na ocasião. $\mathrm{E}$ os três oradores contam seguramente com a aprovação geral dos demais presentes. José de Almeida Camargo é o primeiro a discursar:

Carlota Pereira de Queiroz discursando na Assembléia Constituite. No verso da foto ela marcou 'meu primeiro discurso'

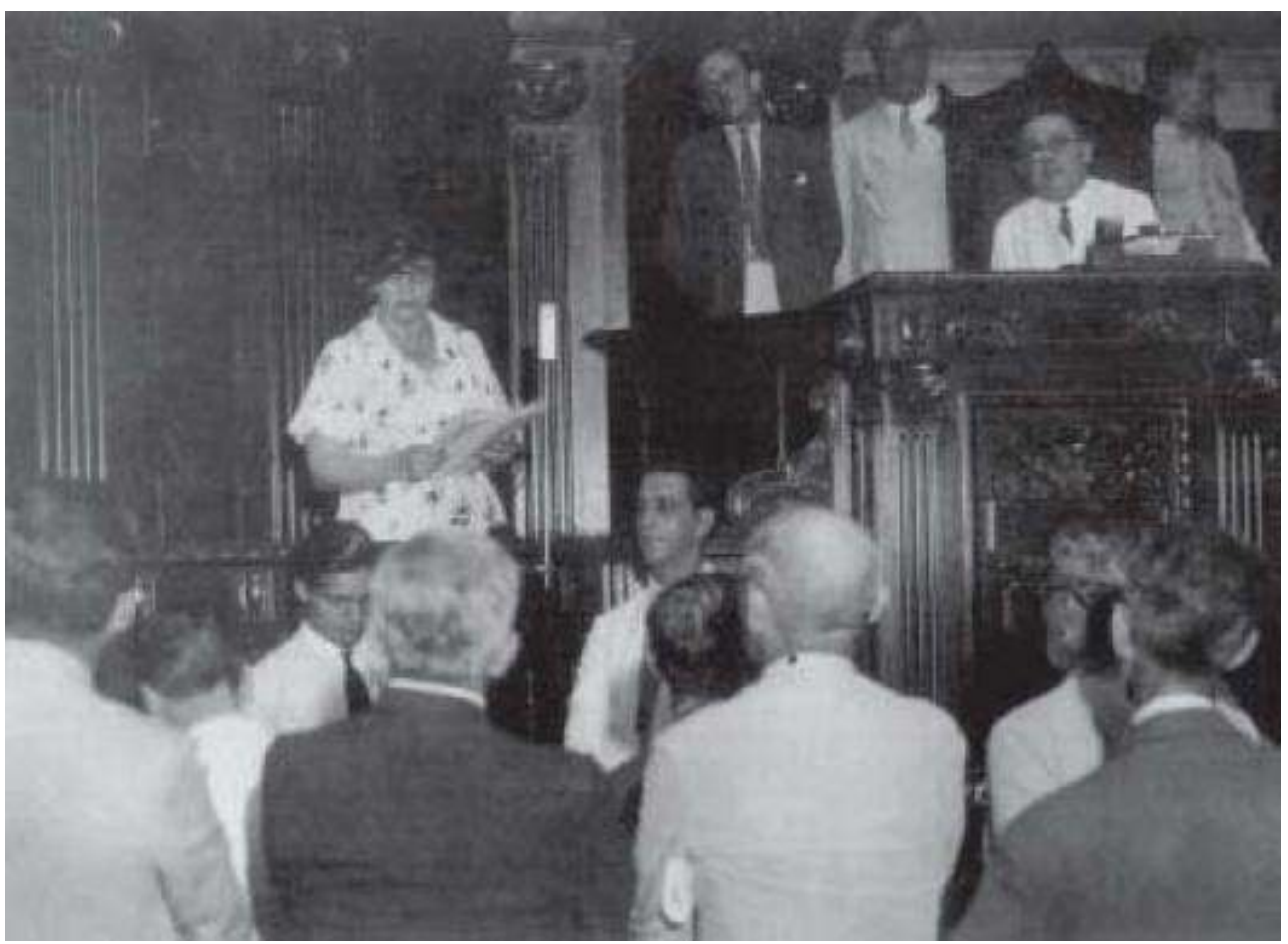

Para São Paulo, porque déstes a elle o esforço laborioso e paciente e fecundo de toda a vossa estirpe, trabalhando, pedra a pedra, como nós, paulistas seculares, para a sua grandeza, na glória silenciosa dos lavradores de fazendas, dos 'violadores de sertões', dos 'plantadores de cidades', dos que recuam meridianos...

(...)

Também sois de São Paulo. Sois paulista. Ser paulista não é só ter uma designação de nascimento ou de interesses immediatos communs. Ser paulista é possuir uma adjectivação, uma qualidade, que só a tradição explica, um futuro, que só a tradição justifica.

Ao que responde a homenageada:

Neste São Paulo da minha veneração e da minha idolatria tenho também todas as minhas raizes. Aqui está a minha verdadeira razão de ser. Na historia do seu passado, que é tambem a dos meus antepassados, encontro o estimulo que me sustenta.

(...)

Antes de terminar, quero assumir um compromisso de honra junto de vós: _ O de amar São Paulo acima de todas as cousas.

Façamos desse sentimento uma religião.

72 Último a falar, José de Alcantara Machado reforça a mesma idéia, começando e terminando sua "Saudação" por: 
Paulista sou, ha quatrocentos anos. Prendem-me ao chão de Piratininga todas as fibras do coração, todos os imperativos raciais.

(...)

Tais palavras, em que pus todo o meu orgulho de paulista, pode faze-las suas, com tanto ou mais direito do que eu, Carlota Pereira de Queiroz.

Bertha Lutz parece subestimar a força desse regionalismo, identificando-se com a luta pela volta ao Estado de Direito levada pelos paulistas que, na realidade, vivendo um momento de reconversão, buscam antes de mais nada recuperar o poder político perdido. A admiração que demonstra pelos acontecimentos ocorridos em São Paulo, nos quais, para aumentar ainda mais seu significado, as mulheres tomam parte ativa, faz com que chegue mesmo a lembrar sua identidade de paulista em mais de uma carta enviada a Carlota. Mas isso não parece bastar diante da importância dada, pelas elites locais, à ideologia das origens ancestrais de seus membros.

Todas essas identificações e diferenças ligam-se, no relacionamento entre Carlota Pereira de Queiroz e Bertha Lutz, a uma divergência fundamental: Bertha é feminista, título que Carlota recusa explicitamente. Em nenhum de seus pronunciamentos ela se refere ao fato de que existiu, antes de 1932, um longo movimento sufragista que poderia ter influenciado em algo sua vitória. Esta se explica, a seu ver, por uma outra conjunção de fatores:

Animada pela voz sublime do clero paulista, que foi a grande inspiradora dos campos de batalha, dos hospitaes de sangue e dos serviços de rectaguarda, realisou o movimento revolucionario de 1932 a mais bella página da nossa Historia.

Acalentada por essas mesmas vozes, cresceu e desenvolveu-se o civismo da mulher paulista, de que a representação feminina na Assembléa Constituinte é hoje uma consequencia directa.

\section{Carlota Pereira de Queiroz assinando a Constituição de 1934}

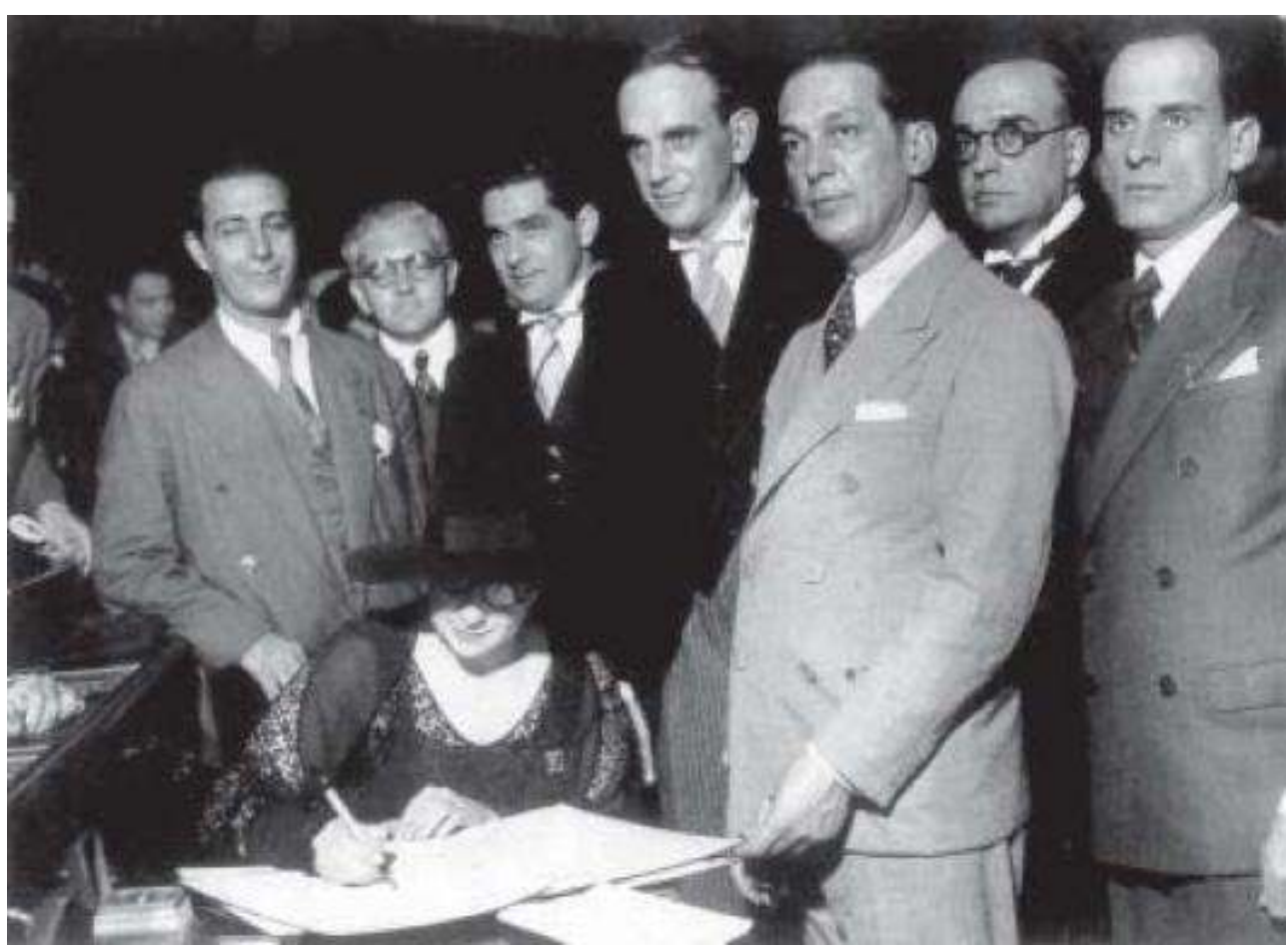

Em pé, da esquerda para a direita: não identificado, não identificado, Antonio Carlos Abreu Sodré, Armando Salles Oliveira, não identificado, Prof. Almeida Júnior, Goffredo Silva Telles Jr. 
E, infelizmente para as feministas, Bertha, apesar de candidata, não consegue eleger-se em 1933.

Enfim, se o tom regionalista que impregna as falas de Carlota encontra ampla receptividade junto a seus pares, a postura que adota enquanto representante feminina na política também não destoa daquilo que pensam outras mulheres de seu estado. Chiquinha Rodrigues, vice-presidente da Bandeira Paulista de Alfabetização, faz as seguintes declarações sobre sua candidatura:

Não alimentamos illusões suffragistas. Desejamos apenas enfrentar as realidades ambientes, e pugnar, com desinteresse, e bastante desprendimento, pelo bem de $\mathrm{S}$. Paulo.

78 Entre os valores que integram o pensamento da gente de Piratininga não se pode pôr á margem a mulher.

79 Dahi o meu enthusiasmo pela candidatura dessa illustrada conterranea. Dando-lhe o meu voto desejo render homenagem á mulher de minha terra. ${ }^{29}$ Numa outra ocasião, encontrando-se Carlota já eleita, a mesma Chiquinha Rodrigues, representando a Federação dos Voluntários de São Paulo, dirige-se a um público formado por feministas, no Rio:

Feminismo. Até onde vae o feminismo em S. Paulo ? Senhoras minhas, a mulher paulista quer para o seu sexo hygiene e cultura, poderação e firmeza, consciência perfeita do que é e percepção plena do que lhe compete fazer na hora presente. Não cogita de reivindicação. $O$ voto lhe é sufficiente neste momento e delle, saberá ella com galhardia costumeira fazer o uso acertado em todos os embates que the surgirem á frente.

(..)

O feminismo da mulher paulista é esse.

81 Nada de reivindicações. O seu trabalho se estende ás obras de assistencia e educação. As iniciativas particulares se multiplicam para protecção á creatura, e sendo assim sem rivalidade nem dissenções, o feminismo triumphará por certo..$^{30}$

Fica difícil avaliar se o apoio prestado pela FBPF foi útil à eleição de Carlota. O que sabemos é que se de um lado ela não o recusa, mantendo relações próximas com Bertha durante todo o período anterior ao pleito, também não o reivindica. Preferindo citar outras fontes de aliança em seus discursos, refere-se sempre a fontes paulistas e, quando femininas, sempre ligadas à benemerência e, sobretudo, à mobilização cívica de 1932:

Sempre acompanhamos em S. Paulo a campanha da classe feminina do Distrito Federal e de alguns nucleos estaduais pela obtenção do voto feminino, mas diretamente nunca contribuimos. Mesmo sem intervenção direta, porem, estou certa de que a nossa colaboração foi eficaz, dando provas concretas da eficiencia do trabalho da mulher. (...)

Em São Paulo, a mulher entrou em ação com a revolução de 1932. E, como sempre acontece nesses fenomenos sociais, sofreu graças a isso uma evolução muito rapida. Quando o voto feminino tornou-se uma realidade encontrou a mulher paulista organizada para recebe-lo, tanto que o eleitorado da sua terra foi o primeiro a consagra-la. ${ }^{31}$

$83 \mathrm{Na}$ verdade, Carlota nunca desempenhou papel relevante nas lutas sufragistas da década de vinte. Seu percurso é outro. Se se distigue incontestavelmente das mulheres de seu meio quando decide seguir a carreira médica, fato pouco comum, seu envolvimento com a política liga-se a um aspecto bem menos heterodoxo de sua ação 
pública: a identificação, generalizada dentre as mulheres das elites paulistas, com a bandeira do constitucionalismo.

Em São Paulo, a benemerência representa, como já vimos, o álibi por excelência que permite às mulheres das camadas dominantes o exercício de uma atividade ao mesmo tempo digna de sua posição e não voltada às responsabilidades privadas. A ação intensiva da Liga das Senhoras Católicas e a envergadura das obras realizadas ao longo de toda a década de vinte é, neste caso, extremamente eloqüente. A urbanização e a atração exercida pelo espaço público paulistano, levam as mulheres a ocupar seu lugar no seio das redes de ação filantrópica. Já bem antes da mobilização de 1932, tais redes respondem a um projeto de assistência aos necessitados que, simultâneamente ao crescimento urbano e à formação da classe operária, caminha de mãos dadas com a política imigratória. As mulheres têm então seu espaço dentro de um projeto social e político mais amplo. Dando assistência, elas trabalham pela integração desses imigrantes, operários, trabalhadores pobres e flutuantes, visando a garantir, ao mesmo tempo, coesão e ordem social. Ao lado dos homens, elas trabalham pelo sucesso do grupo ao qual pertencem, enriquecido pelo café, urbanizado e ainda dominante da cena política nacional.

Após 1930, afastado do poder, o grupo desenvolve inúmeras estratégias de reconversão. Assim, é absolutamente normal ver as mulheres assumirem uma vez mais os ideais de classe e a cumplicidade de antes, travestidos aqui nas expressões de regionalismo examinadas e na mobilização cívica de 1932. Nesse contexto, o discurso e a ação feministas não encontram sua razão de ser, não trazem nenhuma resposta, pois as mulheres conquistam seu lugar de outro modo. $\mathrm{E}$ isso apesar da simpatia que podem sentir por alguém como Bertha Lutz. Não é então por acaso que quando esta vem a São Paulo, é recebida com toda a amizade, recebendo das paulistas uma bandeira do seu estado. Levando em conta a história que lhes é própria, nenhum outro símbolo poderia falar melhor por elas, resumindo tão perfeitamente a mensagem que têm a dar.

Homens e mulheres, unidos num projeto comum, unem-se também, quanto à sensibilidade coletiva, em seu profundo regionalismo e, num falso paradoxo, no profundo cosmopolitismo que tanto os caracteriza - e distingue. Como as protagonistas deste texto, as tão singulares e representativas Carlota Pereira de Queiroz e Olivia Guedes Penteado.

\section{NOTAS}

1. Destaques meus.

2. A correspondente enganou-se ao datar; a carta foi escrita em dezembro, não em outubro.

3. Vale lembrar que Carlota completa 34 anos no final da viagem e D. Olivia completaria 54 pouco depois.

4. Essa atração, aliás, concretamente construída na França durante o século XIX, através de uma imagem e de uma cultura urbana precisas, não atinge somente o Brasil e suas elites. 
5. Carlota Pereira de Queiroz, rascunho de discurso para homenagem póstuma a D. Olivia, manuscrito sem título, s/d ("mais de treze anos após a sua morte").

6. Carlota Pereira de Queiroz, rascunho de discurso para homenagem póstuma a D. Olivia, manuscrito sem título, s/d ("mais de treze anos após a sua morte"). A viagem à Escandinávia foi feita em 1923 : "D. Olivia trouxe-nos [Carlota, sua mãe e sua irmã, em Paris] de automovel e aqui ficou de prosa até mais de meia noite, contando as bellezas da viagem á Noruega." (Carlota Pereira de Queiroz, carta ao pai, 2 de agosto de 1923).

7. Fanny Whately, amiga próxima de Carlota que, junto com a jovem Baby Ramos (Albertina Ferreira Ramos), cuja família mantém relações de amizade com os Pereira de Queiroz, acompanhou Carlota e D. Olivia durante toda a viagem ao Oriente.

8. Bertha Lutz, eleita suplente em 1934, assume seu mandato em 1936, após a morte do deputado Candido Pessoa. Até novembro de 1937, quando o advento do Estado Novo põe fim a esta experiência, elas serão duas a sentar-se no plenário

9. As estimativas de mortos e feridos na Revolução de 32 variam muito. Segundo Joseph Love, os mortos teriam atingido um máximo de 2.100 e os feridos, 7.600. Cf. A Locomotiva : São Paulo na federação brasileira 1889-1937, Rio de Janeiro, Paz \& Terra, 1982, p. 169.

10. Depoimento de uma amiga de Carlota Pereira de Queiroz. Entrevista, 02.04.1996.

11. Depoimento de uma familiar de Carlota Pereira de Queiroz. Entrevista, 01.04.1996.

12. Sobre a ocupação sexuada do espaço urbano paulistano ver : Mônica Raisa Schpun, Beleza em jogo : cultura física e comportament em São Paulo nos anos 20, São Paulo, Boitempo/SENAC, 1999 e Les Années folles à São Paulo : hommes et femmes au temps de l'explosion urbaine (1920-1929), Paris, l'Harmattan/IHEAL, 1997.

13. Note-se que as duas filhas de D. Olivia trabalham ao lado de Carlota, Maria no primeiro organismo e Carolina no segundo.

14. Referência à sua então recente eleição à Assembléia Nacional Constituinte.

15. Carlota Pereira de Queiroz, entrevista a El Hogar, Buenos Aires, 20.03.1935, manuscrito, pp. 3, 5, 7. Destaques meus.

16. Garantido pelo novo Código Eleitoral, promulgado por Vargas em fevereiro de 1932, quando são prometidas eleições para o ano seguinte. Além do voto secreto e obrigatório aos maiores de 21 anos, é introduzido pelo novo Código o voto feminino (e o direito à elegibilidade), ainda que as mulheres de todas as idades recebam o mesmo tratamento que os homens de mais de 60 anos, para quem a obrigatoriedade do voto não se impõe. A Constituição de 1934 estabelecerá a obrigatoriedade do voto para aquelas que exercem função pública remunerada. Cf. Octavio Kelly, Código Eleitoral Anotado, Decreto $n^{\circ}$ 21.076, de 24 de fevereiro de 1932, Iª Parte, artigo 2 e Va Parte, artigo 121, Rio de Janeiro, Oficinas Gráficas Alba, de Moreira e Cardoso, 1932, pp. 14-17 e 112-113 ; Constituição da República dos Estados Unidos do Brasil, Assembléia Nacional Constituinte, Rio de Janeiro, Imprensa Oficial, 1934, Título III ("da Declaração dos Direitos"), Capítulo I ("dos Direitos Políticos"), artigos 108 e 109.

17. A Associação Comercial representa não somente o comércio, mas também as "classes conservadoras", ou seja, industriais e membros da cafeicultura. Ela exerce um papel-chave, coordenando as negociações em torno da composição da Chapa Única. Angela M. de Castro Gomes, Lúcia Lahmeyer e Rodrigo B. Marques Coelho, "Revolução e restauração : a experiência paulista no período da constitucionalização“. In : Angela M. de Castro Gomes (coord.), Regionalismo e centralização política : partidos e constituinte nos anos 30, p. 273. As outras treze associações femininas que sugerem o nome de Carlota são : Associação Feminina Beneficente, Cruzada Pró-Infância, Maternidade de São Paulo, Sociedade de Assistência aos Lázaros, União Universitária Feminina, Frente Única da Mulher Brasileira, Associação Infantil Protetora, Federação Internacional Feminina, Sociedade Pró Arte Moderna, Instrução Artística do Brasil, Sociedade de Assistência aos Exilados Políticos e Suas Famílias, Associação Sanatório Santa Clara e Vanitas. Carlota Pereira de Queiroz, entrevista, s/d, manuscrito, p. 3. 
18. "Além destas duas forças incontestes [PRP e PD], São Paulo ganhara mais uma importante organização política, a Federação dos Voluntários Paulistas (...). Tendo-se articulado imediatamente após a derrota de 32, a Federação dos Voluntários procurara unir os excombatentes, mantendo vivos os ideais da Revolução Constitucionalista e iniciando um movimento de oposição ao então governador militar Waldomiro Lima. (...) Desta forma, a Federação afirmava-se como uma importante e ativa corrente de opinião no estado, e mesmo sem assumir a forma de partido político expandia-se e formava núcleos em diversos municípios e distritos do interior. Qualquer iniciativa de composição de grupos políticos em São Paulo em torno da defesa dos ideais constitucionalistas e da oposição ao governo de Waldomiro Lima teria, necessariamente, que considerar a Federação dos Voluntários e sua proposta de renovação política. Angela M. de Castro Gomes, Lúcia Lahmeyer e Rodrigo B. Marques Coelho, op. cit., p. 269. De fato, dos 22 membros da Chapa Única, 3 são indicados exclusivamente pela Federação dos Voluntários, e eleitos ; e 9 são indicados pela Federação junto com alguma das outras forças políticas envolvidas (PRP, PD, Associação Comercial ou LEC), 8 dos quais se elegem. Carlota Pereira de Queiroz pertence ao C.O.P. Central da Federação dos Voluntários, pedindo licença do cargo, em janeiro de 1934, para cumprir seu mandato no Legislativo.

19. ACF, Associação de Assistência às Famílias dos Exilados, Instrução Artística do Brasil, Associação Feminina Beneficente e Instrutiva, Cruzada Pró-Infância, Lar São Paulo, Associação Beneficente Paulista, Centro de Estudos e Ação Social, Obra de Preservação aos Filhos dos Tuberculosos, Liga do Professorado Católico, Conselho Superior das Damas de Caridade de S. Vicente de Paulo, Federação Internacional Feminina, Frente Única da Mulher Brasileira, Sociedade União Infantil, Dispensário N. S. de Lourdes, Tarde da Criança, Clínica Infantil do Ypiranga, Legião de São Paulo, Federação das Pias Uniões das Filhas de Maria. Liga das Senhoras Católicas da cidade de São Paulo, Relatório da administração 1933-1934, pp. 114-121.

20. Carlota estudou Medicina no Rio, tendo morado ali de 1923 a 1926.

21. Aparentemente, o presente é uma iniciativa de Carlota ; a lista com os nomes é escrita por ela, à mão, e inclui : Elisa Botelho, D. Olivia Penteado, D. Perola Byington, Edith Capote Valente, Nisia Capote Valente, Elisa Quadros, Carlota P. de Queiroz, D. Albertina Gordo, D. Alice Tibiriçá, Branca Canto e Mello, Clotilde Kleiber, Annita Malfatti, Zizi Moreira, Maria Luiza Pereira de Queiroz, Maria Augusta Costa Leite, Vicentina Carvalho, Marietta Lion, Noemia Nascimento Gama, Miloca N. Vicente Azevedo, Albertina Almeida Prado, Marietta M. Prudente Moraes, Ophelia Fonseca, Herminia Pires de Campos, Elisa Rezende Puech, Nair Mesquita, Fany Doria, Cornelia Fagundes, Luizita Gama Cerqueira de Carvalho, Iracema Niebler, Baby Gonçalves, Baby Pereira de Souza Jordão, Zenaide Andréa. Carlota Pereira de Queiroz, manuscrito, s/d.

22. Trata-se de D. Olivia.

23. No dia anterior, Bertha havia escrito uma carta onde também aborda esta questão : “Agora o que acho essencial é vocês tentarem o quanto antes, uma manobra junto a todos os partidos para que no conchavo que propalam que se fará em S. Paulo, se dê um lugar a uma representante feminina. (...) Aqui vamos procurar obter apoio para uma. Em Pernambuco está lançada uma candidatura feminina. Peço que você reuna o pessoal mais inteligente, e as senhoras ilustres como D. Olivia, Luisita, Perola etc e vejam se não seria boa idea pedirem a todos os grupos que entre uma mulher no conchavo." Bertha Lutz, carta a Carlota Pereira de Queiroz, 24 de março de 1933.

24. Diário da Noite, São Paulo, 03.04.1933, primeira página, "Dra. Carlota Pereira de Queiroz".

25. Diário da Noite, São Paulo, 30.03.1933, "A Campanha pelo Voto“.

26. Cf. O Estado de S. Paulo, 08.04.1933, "A Situação", "Mensagem da Mulher Paulista“. O texto termina dizendo que a lista de assinaturas fica aberta àquelas que quiserem incluir seu nome, na redação da revista Vanitas (publicação dirigida por Nair Mesquita). Segundo Carlota, essa lista teria reunido mais de 500 assinaturas. Cf. Carlota Pereira de Queiroz, entrevista, manuscrito, s/d. Destas, consegui localizar 292, nas quais se incluem as 65 publicadas no manifesto citado. 
27. Folha da Noite, São Paulo, 12.04.1933, "Declarações da Dra. Carlota Pereira de Queiroz, a representante da mulher paulista na Chapa Única".

28. Homenagem a Doutora Carlota Pereira de Queiroz - $1^{\underline{a}}$ Deputada Brasileira, São Paulo, São Paulo Editora Ltda, s/d.

29. Diário da Noite, São Paulo, 11.04.1933, "A Candidatura da dra. Carlota Pereira de Queiroz à Constituinte".

30. Almoço oferecido pelas Associações Femininas do Rio à Primeira Deputada Brasileira Dra. Carlota Pereira de Queiroz, Rio de Janeiro, Oficinas Gráficas do Jornal do Brasil, 1934, pp. 11-12.

31. Carlota Pereira de Queiroz, entrevista, manuscrito, s/d. 